\title{
A COMPARATIVE ANALYSIS OF TENDER SUMS AND FINAL COSTS OF PUBLIC CONSTRUCTION AND SUPPLY PROJECTS IN NIGERIA
}

\author{
OLATUNJI, Oluwole Alfred
}

Directorate of Physical Planning,

Office of the Vice Chancellor,

Federal University of Technology

P. M. B. 704, Akure

Ondo State, Nigeria 340001

Pastorolatunii alfred@yahoo.co.uk

+2348035811764

March 2008 


\section{A COMPARATIVE ANALYSIS OF TENDER SUMS AND FINAL COSTS OF PUBLIC CONSTRUCTION AND SUPPLY PROJECTS IN NIGERIA}

\section{ABSTRACT}

\section{Purpose}

The purpose of this study is to investigate the relationship between tender figures, consultants' figures and final construction costs of construction projects under competitive bidding in the Nigerian construction industry, as guided by the Due Process policy, a national public procurement reform programme.

\section{Methodology}

13 construction professionals and public contract administrators were interviewed. Their views were reported intermittently as the secondary data collected on 137 construction projects (95) and supply projects (42) are being analyzed and discussed.

\section{Findings}

The study presents a number of regression models which can be used to predict the final cost and actual duration of construction and supply projects under the Due Process regime on Nigeria as functions of lowest bids, consultant estimates, successful bid, gross floor area, average bid, contractor's proposed contract duration and the consultant's proposed contract duration.

\section{Practical Implication}

The discovered models, apart from being worthy benchmark for future study triangulation, can be of immense use to developing countries with the intention of implementing the Due Process policy of Nigeria in the countries as the limitations of the Reform were succinctly discussed. Moreover, with the growing prospect for heavy engineering projects, the study will be of good use to intending international contractors willing to explore the Nigerian 
construction market, either by holistic participation or by forming partnership or alliances with Nigerian domestic firms.

\section{Originality}

The paper presents one of the pioneering stochastic studies based on empirical data on construction and supply projects under the Due Process Reform in Nigeria.

Paper Category: Research Paper

Keywords: Bid offer, Due Process, tender action, value, Nigeria 


\section{INTRODUCTION}

Latham (1994) and Egan (1998) define construction client as the single most imperative party whose opinions primarily matter at the end of the day. Other parties' roles are more of facilitative and secondary, but no less important are certain systematic, integrative and collaborative arrangements in the continuum of the defragmentation process of the building process. Per se, these arrangements are defined by certain variables of client satisfaction in the construction industry, viz;

1. The right construction cost that optimizes the highest value for money.

2. The right timing for project delivery that institutionalizes timely responsiveness of projects to projected return.

3. Highest premium of quality performance of projects at the value not less that the highest possible comfort and satisfaction achievable as prescribed in the functionality and aesthetic scope of client expectation.

4. All clients would desire achieving their prescribed projects at minimal or no threat to health and safety expectation of client and end users all through the project's intact life, and;

5. Also desirable is the acquisition of best quality service in the construction product development process without undue exposure to adversary and confrontation against sustainable mutual understanding, value sharing and innovative job relationship (Kometa et al, 1995; Barton, 2000; Olatunji and Aje, 2005c).

Hatush and Stikmore (1997a) observe that achieving all the aforesaid is a difficult challenge in the construction industry. Due to major economic and technical constraints, developing countries with strong desire and potential for infrastructural development like Nigeria are not left out in the this challenge. Omole (2001) reports that government is the largest construction client in Nigeria, with major interest in public projects. However, due to extensive military influence on the Nigerian construction industry before the recent advent of democracy in Nigeria in 1999, contractor selection has been subjective and corruption ridden because public contracts are not awarded on 
merit to contractors but cocooned by informal relationships with complex corruption problems (Obiegbu, 2005). As a result, major construction and supply contracts are awarded to incompetent contractors under questionable circumstances at costs that have little or no relationship with consultants' estimates. In many cases, contractors or suppliers might be mobilized with 15 - $40 \%$ of contract cost without satisfactory commitment on site while most contract figures are often inflated or project abandoned while the contract is still valid, without responsive challenge from relevant stakeholders.

In order to redeem the image of the Nigerian construction industry, largely seen as the single largest hub of public fund mismanagement, the Due Process Policy was instituted in 2002 to entrench the ethos of professionalism, respect for best practices and the prioritization of merit in the contractor selection processes and procedure for all public contract procurements (BMPIU, 2005). This study is therefore aimed at investigating the performance of construction and supply projects in the Nigerian construction industry with respect to tender and construction cost and time under the Due Process Policy between 2003 and 2007. The study objectives are set as follows:

1. To compare the variance between tender and final figures of construction and supply projects in terms of cost and time.

2. To develop models for the forecast of tender and final figures of construction and supply projects in terms of cost and time.

3. To compare the construction project in terms of cost and time.

Based on the foregoing, the combination of construction and supply projects for investigation in this study defines its heterogeneous instinct. However, the scope is limited to the consideration of some comparable features in terms of tender and final cost and duration of contracts only.

\section{LITERATURE REVIEW}


Construction client can be defined under different denominations. Bjonfot and Stehn (2007) define construction client as the employer, not limited to the overt, inadvertent or express financier of a project, in broader terms it may include the end user of the proposed project and the general public at large. Thus, the variability of client requirement and expectation in the industry might be subjective, imprecise, inexhaustible and complex. Pearl et al., (2005) argue that the capacity of client; whether individual, corporate or public vis-àvis the nature of their business and the pre-defined target specification are part of the fundamental integrals in the risk flow mechanics in the product development process. Also, Hatush and Skitmore (1997a \& 1997b) also argue that the ultimate goal of any construction client is to maximize value for money. There are many empirical evidences that the most popular orientation of the construction industry towards achieving this is the use of competition as the single largest catalyst in creating value for money in the construction process.

Moreover, there are numerous empirical evidences that the construction industry has a history of achieving short-term goals, without reaching sustainable, long-term objectives for which construction clients earnestly desire and would ultimately prefer to achieve (Scott et al., 2004). To this end, the image of the industry has not been the best in recent history. There are reports of attempts made towards solving the avalanche of challenges confronting the industry. Bartelson (2003) reports that understanding the complexity in the nature of construction industry as explicated in the nature of client requirements vis-à-vis the nature of the construction product development processes is a key to generating a comprehensive purview of the outlay of the peculiarity and uniqueness of the construction product development process.

\section{The variables of project performance}

Therefore, the measurability of project performance is a function of client satisfaction in relation to the roles and responsibility of professionals involved in the construction process game (Latham, 1994; Ho and Ng, 2003; Gray, 
1996; Olatunji, 2006f; Gruneberg and Hughes, 2006). Hatush and Skitmore (1997a and 1997b) report that all construction clients will desire a timely achievement of their construction product, within the cheapest limit of cost as much as possible without giving compromise to value for money as to the maximum quality of product achievable. Merna and Smith (1990) also argue that apart from cost, time and anticipated quality of construction product; risk, in its different forms of denominations, is a hydra-headed variable that is inevitable in the computation of any workable model that correctly predicts the reliability and variability instincts of the construction development process.

There are empirical and stochastic research reports that comprehensively present the relationships between the variables of project performance in terms of cost and time as being interwoven (Elinwa and Buba, 1993; Elinwa and Joshua, 2001; Kaka and Price, 1991; Okuwoga, 1998; William, 2003; Chan, 2001; Chan and Kumaraswamy, 1999; Jackson, 2002; Omorwgie et al., 2005). Moreover, Endut et al (2005) report how devastating the effects of cost and time overruns could be in construction, while Aibinu and Jagboro (2002) report the evasiveness in the trend of cost overrun in the Nigerian construction industry, which was put at about $18 \%$ above budgeted limits. Therefore, it is evident that the construction industry has challenging history of poor cost performance in which case there is the demand for continuous efforts towards finding solutions to the hydra-headed menace of systemic poor cost performance in the construction product development process.

Since the client holds the biggest stake in decision making (Latham, 1994), he reserves the mandate to significantly influence the distribution of roles, responsibilities and risks in the process among the systemic stakeholders. Gruneberg and Hughes (2006) report that this aspect of risk and value sharing between the client and the contractor is a major reference point in the outlay of success factor in the construction gaming instincts. The systemic conflict of interest is imbedded in the client's drive towards achieving value for money. Gray (1996) and BMPIU (2005) argue an attempt to defining competition as a global best practice towards spurring innovation and value sharing as a major misconception in the industry. Competition has not been 
the best fulcrum of the true spirit of collaborative, integrative and equitable risk sharing among the gamers in construction contracting (Drew and Skitmore, 1990; Doree, 2004).

Unfortunately, perhaps due to economic recession and client's delimited economic power, contractor selection in the construction industry is mostly cost-led instead of being value-led (Gould, 1998; Gorse and Emmitt, 2004). Sutrisna et al., (2005) argue that in contractor selection driven by price-dataonly, the best value of contractor's offer could never be optimized. This is largely as a result of the fact that determining and controlling the cost of construction in a scenario whereby the contractor is to wholly bear all risks is subjective and could lead to dysfunctional dispute and crisis due to the winlose orientation in such method of contracting. To this, Bresnen and Marshall (2000) argue that even an integrated collaborative instinct promised by partnering and its job-relationship sustenance derivatives are not absolute solutions to solving the challenge of the cultural mis-alignment between cost and value in the contractor selection process in the industry.

On the one hand, many contractors are mostly desperate to win contracts without considering the stochastic analysis of the risks inherent in the project. Also, economic variable and ethical dynamics are the largest critical factors that are responsible for the cultural mis-alignment distorting the realistic performance of variables of competition in construction (Polingkton, 1999; Gray, 1996). On the other hand, construction clients always misconceive negotiating a contract to the lowest tender figure of cost as the best way to creating value for money in the construction process. Such scheme is merely subjective, short-sighted and risky as the project reserves the lowest standard of work that the value invested can buy at that point in time. Meanwhile, the structure has no surety for sustainable performance in the product life cycle (Ho and Ng, 2003; Ho et al., 2004; Hatush and Skitmore, 1997a, Knight and Morledge, 2005).

\section{The Due Process Policy in Nigeria}


Just like many other relative developing countries, the Nigerian construction industry was sometimes seen as the largest fulcrum of corruption in public contracting due to the fact contractor selection is largely subjective, bias and imprecise (BMPIU, 2005). Therefore, there was the need to optimize and integrate objectivity in contractor selection as a national ethos in public contract procurement. To this end, there was a public procurement reform from the Presidency, the purpose of which is to sanitize the public procurement system in Nigeria by ensuring that contractor selection process follow a routine of certain rules such that public contract are awarded to competent contractors only. The selection of such contractors must be determined competitively, objectively and openly through prequalification process. Contractors are invited for prequalification through advertisements in major national publications in response to which intending contractors are expected to submit certain information considered imperative to the level of competencies required for the successful implementation of the proposed project. Details of such variables are reported by Olatunji and Aje (2005c) and Ogunsemi and Aje (2005). After prequalification assessments (largely paper based), candidate contractors with higher scores are noted to be competent and are then invited for bidding through another round of wide advertisements in major national print media as well as formal contact, The policy believes that free competition through the bidding process is a fulcrum of value for money, especially when only competent contractors are left in the race (BMPIU, 2005) .

Based on the foregoing, all public contracts are to follow this procedures before they can be certified to have followed Due Process without which they can not be approved for execution by the Due Process Office and subsequently access the national treasury for funding. Subsequently, all accepted tender figures are approved as project budgets and such must be held tight against cost-overrun. On the other hand, despite the crusade for objectivity in contractor selection mechanics in the construction industry, the overall success determinant is the tender price. Hatush and Skitmore (1997a) reports a number of approaches used in some countries. Mainly, it is a common practice in the construction industry to consider the lowest bid as 
realistic, but mostly not without certain bonding conditions. However, there are instances where the average bid, being the mean of all the tender figures, is considered as a very reliable reference. There can be few instances too whereby due to lack of competition in the tender action, the highest bid may be the most realistic bid if offered by specialist tenderer in a non perfect competition. In all, best practices in construction uphold the fact that as long as a contractor succeeds in prequalification as being buoyant to perform under stipulated conditions of contract, the over-riding selection principle is to adopt the lowest bid as the most viable reference generated through competition (BMPIU, 2005). In 2005 alone, the policy was reported to have saved the government about $\mathbf{N 1 3 7 , 0 0 0 , 0 0 0 , 0 0 0}$ (over US\$1b). Although, different countries have different approaches of appropriating cost-led factors as the most important fulcrum of best practices in contractor selection in relation to creating value for money in construction (Hatush and Skitmore, 1997a), the regret; however, is that the procurement process is devoid of realistic competition (Doree, 2004; Ray et al, 1999), thus project delivery in the construction industry may be at best a furlough hope.

\section{RESEARCH METHOD}

Historical data were collected for analysis from Federal government establishments that are strong adherents of the new public contract procurement system, the Due Process policy. The establishments were randomly selected because the representation of the industry's image was supposed to be even, since all public contract procurements are streamlined to follow a common template of processes and procedures, viz; project packaging, advertisement, prequalification, invitation and bidding, Due Process Certification, award and execution. Interviews were also conducted on contract administrators and contractors who have experienced the pre and the post Due Process policy era. The projects selected for analysis are heterogeneous in nature because the material for the study is a combination of construction and supply projects to some academic institutions in Nigeria. 
The 13 interviewees whose opinions were reported have a minimum of 8 years cognate experience in public sector contracting and a maximum of 21 years of experience. The fact that the respondents' average years of experience is 13 years implies that even if the opinions generated and reported in this study does not represent the absolute picture of the industry, whether in Nigeria, Africa or the rest part of the world, however, it can be regarded as a significant representation of popular opinion that could be relevant in other similar area of application. Interestingly, all the respondents are professionally qualified and have registered as recognizable construction professionals in Nigeria. Table 1 shows the breakdown of the professional backgrounds of the respondents. From the analysis of the demographic background of the interviewees, there are 4 Architects in all the denominations of respondents with an average of 18.25 years of experience. There are 3 each of Engineers, Quantity Surveyors and Builders with average years of experience of 12.67, 13.33 and 9 years respectively. However, the respondents are not from the same establishments, but because of the similarities in the orientation of their firms and the nature of their roles in such firms, their opinions were integrated as materials for the study.

Furthermore, analysis on the demographic background of the respondents reveals that the interviewees from consulting background have executed an average of 5 projects under Public Contract Procurement Reform (2002), the Due Process policy, between 2003 and 2007, while the contracting firms interviewed have executed an average of 31 public contracts under the Reform. Interestingly, the respondents from the public service sector have executed an average of 51 projects within the same period. The variance in the number of projects executed by the firms could not be separated from the fact that, from the orientation of the Reform, the policy is public sector oriented. However, the fact that the interviewees from the consulting firms randomly selected have only executed 5 projects within the 5 years (2003 2007) used in this study does not mean an absolute picture of the Nigerian construction industry or the level of patronage of consultancy services in the industry. 


\section{Insert Table I}

The data used for this study were collected on 137 public contract projects executed under the Due Process policy between 2003 and 2007 in Nigeria. Table 2 shows the breakdown of the nature of projects. Analysis reveals that about $41 \%$ of the projects under review are building construction projects, about $28 \%$ are civil engineering projects, while about $31 \%$ are for supply of equipments. Also about $54 \%$ of the building construction contracts are new construction projects, while about $46 \%$ are building rehabilitation contracts. Meanwhile, all the projects under review are educational projects such that the types of building construction projects include the construction and rehabilitation of students' hostels, academic buildings, social structures, sporting facilities, administrative buildings as well as residential houses for university staff on campus. Also, about $12 \%$ of the projects are donated projects while the larger percentage is sponsored by the Federal government.

\section{Insert Table 2}

Moreover, the civil engineering projects are largely new road construction projects or the rehabilitation of the existing ones. However, about $28 \%$ of the projects under this schedule are for the construction of pedestrian walkways, construction of stone-pitched surface drainages and so like. The contracts for 
the supply of equipments include the supply of Information and Communication Technology (ICT) equipments and software to the library, supply of furniture items for administrative, residential, social and academic purposes as well as research laboratory equipments.

\section{DATA ANALYSIS}

\section{Analysis on Construction Projects}

Tables III - VI show the tabulation and analysis of the study materials as per the year of award, lowest tender figure, average tender figure, consultant figure, successful bid, final contract sum, proposed contract period, actual contract period and percentage differences in actual and budgeted contract cost and period.

\section{Insert Table III}

From the data available, it was discovered that there were different behavioural patterns in the variables of project performance in construction (building and civil engineering) projects and supply contract contracts, hence the need to analyze the data collected separately. In all, there were 95 construction projects, $58.9 \%$ of which are building projects and 47 supply projects. All the projects analyzed were undertaken and procured using Due Process procedures (BMPIU, 2005) between 2003 and 2007. All other projects have been completed.

Interestingly, all construction projects are awarded on lowest bid basis. To this end, the interviewees advised that although it may be enticing to pick the 
lowest bid based on price data only after prequalification - since the quality and competence of the contractors are noted to be satisfactory, however this has not been an advantage under the Due Process policy. Apart from the fact it debilitates competition as some contractors are still found bidding with very ridiculous rates, low quality of workmanship and project's poor performance in its entire life are probable features of many public construction products in Nigeria. Moreover, since the system is to optimize competition, innovation and value-sharing towards optimizing client's value for money some other aspects of this analysis would establish the relationship between contractors prequalification and contractors' competence and performance under the Due Process.

Regrettably, there are serious variants between consultants' proposed projects costs and award figures and final construction costs and completion periods for the construction contract data used for this analysis. Analysis reveals that construction clients under review in this study took lowest bid figures which were completed to the tune of $-84.23 \%$ and $+808.66 \%$, being deviations of contractors' intents from consultants' cost projections. In other words, instead of the popular belief that tender proposals are only safe for consideration if they fall between -5 and $+5 \%$ of consultant estimate, the final construction costs used for this study range from about $85 \%$ less than consultant estimate and about $810 \%$ more than the consultant estimates. On the other hand, the deviation between consultants' time estimates and the actual construction period is between $-99.23 \%$ and $808.66 \%$.

The implication of the foregoing is a revelation of the fact that in rare cases, some consultants can be negligent, taking certain decisions that can be damaging to client interest due to their inability to capture client's requirements as due (Poon, 2003). On the other hand, there can also be few cases whereby professionals can over-estimate construction cost with a view to claiming outrageous contingent fees from unsuspecting clients (Olatunji, 2007c). However, it takes a committed client to be consistently involved in the project development process in construction and faithful contractor to achieve considerable result in the construction process as well as the co-operation of 
the consultants (Kometa et al., 1995). It is worthy of note that in all the projects reviewed, there were no records of major variation orders and fluctuation claims.

However, only about $28 \%$ of the projects were awarded responsively in reference to consultants' projections (between -5 and $+5 \%$ ). Obviously, there is no limit to the desperation of many construction clients, possibly because of the recessionary incursions of the economy, to achieve the procurement of their projects at the lowest possible cost, not minding the risks and pressures under which the contractor is being put. To this, respondents interviewed opine that cost-based competition, at the short-run, is still regarded as the most popular and the single largest model for initiating value for money in the contractor selection process adopted by many faculties in the construction industry.

On the other hand, the information provided at this point is a clear indication of the poor run of professionalism in the construction industry. The instinct of subjectivity and impreciseness is systemic in the process (Merna and Smith, 1990). Mostly, certain professional opinions, procedures and actions are unintentionally damaging to client's interest (Poon, 2003), while uncertainty in the process and the nature of client requirements vis-à-vis the comprehensive transmission of client's intention through the project Brief and the Bill of Quantity (BoQ) is a major challenge (Tse et al., 2005). While there are serious critique arguments depicting certain professional services as being unnecessary and irrelevant to client's goals, the empirical information also confirm Sutrisna et al (2005) who opine that the experience of construction contractors may pay-off in predicting realistic estimates through project-based account of effective cost management, monitoring and controlling rather than the rigid bespoke contract documentation process common to popular Bill of Quantity (BoQ) format in consultants, faculties in construction. Obviously, this system may be allergic to debilitating job relationships and proliferating evitable dysfunctional dispute in the traditional procurement system. 
Moreover, the discrepancy between the lowest bid and the actual construction cost ranges between $-84.79 \%$ and $+111.05 \%$. While about $45 \%$ of the projects under analysis were completed below the proposed cost, about $15 \%$ finished were delivered with about $5 \%$ cost over-run. In the course of the interview, it was discovered from interviewees' opinions that cost performance in the construction industry is largely a function of professional ethics and people issues. In this sense, it is evident that quite a large percentage (about $40-55 \%$ in the case presented in this study) could not be achieved within the anticipated cost limit possibly because the professionals involved lack the technical astuteness and the right behavioural orientation to manage professional opinions in terms of serious ethical dilemmas or allied challenges. A parallel research is being conducted to update Olatunji (2006f) as in the relationship between professionalism and construction project performance under Due Process policy.

Regrettably, only about $5 \%$ of the projects analyzed were delivered as proposed, while the overview of the time of project delivery reveals that project were delivered between $-25 \%$ and $300 \%$ deviation from as proposed. Consultants' time estimates were not exact; only $5 \%$ were exact, $5 \%$ were less. The range of variance in deviation from consultants' time estimates is between -58.33 and $500 \%$. There was no record of enforcing the Liquidated and Ascertained Damages caution on any of the projects. This, the author suggests, has a direct relationship with the level of discrepancies in the virtues of client commitments in terms of cash-flow to the contractor, thus the scenario puts the contractor in a difficult position to optimize effective planning. Interviewees assert that quite a large percentage of the contractors that were patronized did not have the right technique for effective project planning towards timely delivery of projects. Regrettable, there is a very poor record of training facility for contractors' management decision makers in many developing economies, thus an improvement may not be feasible in the nearest future except something urgent is done.

Interestingly, further analysis using SPSS (11.0) reveals that there is strong correlation between almost all the variables. Using, Pearson and Spearman's 
Correlation techniques correspondingly, almost all the variables strongly correlate either at 0.01 or 0.05 significance level. Table IV shows the details of the correlation analysis of all the variables of project performance with respect to the facts and data presented in this study.

\section{Insert Table IV}

Moreover, the data available were rigorously subjected to Regression analysis to create some models in the system. This type of method of analysis was used in Smith (1998) in which the prediction of the outcomes of certain variables in construction were considered or defined in stochastic pattern. The model format is given in Equation I. Ultimately, the models are extensively expected to predict project variables like Final Construction Cost and the Realistic Construction Period under the Due Process policy in Nigeria being the function of the reliability of the variables in the data available for the study.

$Y_{0}=a_{0}+a_{1} x_{1}+a_{2} x_{2}+a_{3} x_{3}+\ldots . a_{n} x_{n}$ Equation 1

Where $Y_{0}=$ Dependent Variable

$\mathrm{a}_{0} \ldots \mathrm{n}=$ Constants and coefficients of variables

$\mathrm{x}_{1 \ldots \mathrm{n}}=$ Independent variables

Predicting the Final Construction Cost, a model presented in Equation II was discovered. Tables IV(a) and (b) show the summary of the model variables and milestones.

$F_{n}=0.524 x_{1}+0.448 x_{2}+0.001331 x_{3}+46.986 x_{4}-748956$ Equation II

Where $F_{\mathrm{n}}=$ Final Construction Cost

$\mathrm{x}_{1}=$ Lowest/Successful bid

$\mathrm{x}_{2}=$ Average bid

$\mathrm{x}_{3}=$ Consultant's cost estimate 
$\mathrm{x}_{4}=$ Gross Floor Area

Table IV(a): Summary of Cost model variables and coefficients

Coefficients

\begin{tabular}{|c|c|c|c|c|c|c|}
\hline \multirow{2}{*}{\multicolumn{2}{|c|}{ Model }} & \multicolumn{2}{|c|}{$\begin{array}{l}\text { Unstandardized } \\
\text { Coefficients }\end{array}$} & \multirow{2}{*}{$\begin{array}{c}\begin{array}{c}\text { Standardized } \\
\text { Coefficients }\end{array} \\
\text { Beta } \\
\end{array}$} & \multirow[b]{2}{*}{$t$} & \multirow[b]{2}{*}{ Sig. } \\
\hline & & B & Std. Error & & & \\
\hline \multirow[t]{5}{*}{1} & (Constant) & -748956 & 889905.3 & & -.842 & .402 \\
\hline & VAR00001 & .524 & .127 & .509 & 4.135 & .000 \\
\hline & VAR00002 & .448 & .119 & .468 & 3.758 & .000 \\
\hline & VAR00003 & $1.331 \mathrm{E}-03$ & .013 & .003 & .105 & .917 \\
\hline & VAR00006 & 46.986 & 1958.682 & .002 & .024 & .981 \\
\hline
\end{tabular}

a. Dependent Variable: VAR00005

Table IV(b): Cost Model milestones summary

Model Summary

\begin{tabular}{|l|r|r|r|r|}
\hline Model & $\mathrm{R}$ & R Square & $\begin{array}{c}\text { Adjusted } \\
\text { R Square }\end{array}$ & $\begin{array}{c}\text { Std. Error of } \\
\text { the Estimate }\end{array}$ \\
\hline 1 & $.975^{\mathrm{a}}$ & .951 & .949 & 5053244.97 \\
\hline
\end{tabular}

a. Predictors: (Constant), VAR00006, VAR00003, VAR00001, VAR00002

With $R, R^{2}$ and Adjusted $R^{2}$ values being $0.975,0.951$ and 0.949 respectively, obviously the model is both about $95 \%$ fit and strong for reliance with most of the needed elements in reliable order of significance taken at $5 \%$.

From the model derived above, intending local and international contractors willing to tender under the competitive pool of contractor selection process under the Due Process policy in Nigeria will find the model useful to predict the final construction cost if the lowest bid, which has mostly been taken as the successful bid, is known as well as average bid of all the tender figures available for the project, the consultant estimate and the gross floor area.

Developing a Realistic Time model for construction projects based on the analysis of the data available for this study, Equations III and IV were discovered, while Tables IV(c) and (d) show the model summary for the model presented in Equation 3, while Tables IV(e) and (f) show the summary for the model presented in Equation 4.

$\mathrm{Tm}_{\mathrm{t}}=8.32+0.387 \mathrm{x}_{1}-0.00109 \mathrm{x}_{2}+0.898 \mathrm{x}_{3}$ Equation III 
Where $\mathrm{Tm}_{\mathrm{t}}=$ the Real project duration (with Time dependent variables)

$\mathrm{x}_{1}=$ Consultant's Time projection

$\mathrm{x}_{2}=$ Gross Floor Area

$\mathrm{x}_{3}=$ Time proposed by the Contractor

Table IV(c): Summary of Time model variables and coefficients (Time dependent)

\section{Coefficients $^{\mathrm{a}}$}

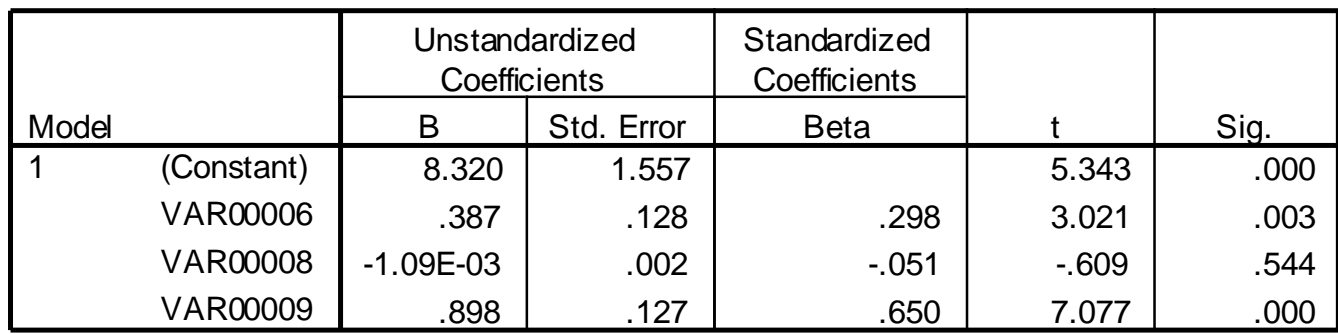

a. Dependent Variable: VAR00010

Table IVd: Time Model milestones summary (Time dependent)

Model Summary

\begin{tabular}{|l|r|r|r|r|}
\hline Model & $\mathrm{R}$ & $\mathrm{R}$ Square & $\begin{array}{c}\text { Adjusted } \\
\text { R Square }\end{array}$ & $\begin{array}{r}\text { Std. Error of } \\
\text { the Estimate }\end{array}$ \\
\hline 1 & $.871^{\mathrm{a}}$ & .758 & .750 & 7.98206 \\
\hline
\end{tabular}

a. Predictors: (Constant), VAR00009, VAR00008, VAR00006

In this instance, the $R, R^{2}$ and Adjusted $R^{2}$ values are $0.871,0.758$ and 0.750 respectively, obviously the model is both about $75 \%$ fit and strong for reliance with most of the needed elements in reliable order of significance taken at $5 \%$.

Moreover, if the consultant's time projection is known as well as the gross floor area, the model could be used to predict the real construction time based on the contractor's time projection. However, from Equation III, the gross floor area is negatively correlated with the real project duration because based on the data available, there are major constraints to work flow which impact on the competences of the contracting firms' performances on the job. A typical challenge is cash flow problem and the inherent bureaucratic bottleneck in government business which can affect contractors and their projects 
differently. Moreover, since prequalification score is not a factor in bid acceptance, it implies the most competent contractor may not likely get the job if the mark-up for overhead costs and profit is too high. This means, as the contractors differ in competences their abilities to maintain firm standard in project management differs, their commitment to project management through incentives and motivation for workers also differs. A study on the relationship between motivation and incentive and project delivery in Nigeria is presented in Olatunji (2007f). This implies, the speed of project execution in the Nigerian construction industry is largely dependent on certain factors (like corporate standard and policy, incentives for workers, cashflow etc) and not necessarily dependent on the gross floor area of the project.

On the other hand, integrating cost element into the variables, Equation 4 was discovered.

$\mathrm{Tm}_{\mathrm{c}}=7.481+0.912 \mathrm{x}_{1}-0.0000001749 \mathrm{x}_{2}+0.451 \mathrm{x}_{3}+0.00266 \mathrm{x}_{4} \ldots$. Equation IV

Where $\mathrm{Tm}_{\mathrm{c}}=$ Real project duration (Cost dependent)

$\mathrm{X}_{1}=$ Proposed Time projected by Contractor

$\mathrm{X}_{2}=$ Lowest/Successful bid

$\mathrm{x}_{3}=$ Proposed Time projected by consultant

$\mathrm{x}_{4}=$ Gross Floor Area

Table IVe: Summary of Time model variables and coefficients (Cost dependent) 
Coefficients $^{\mathrm{a}}$

\begin{tabular}{|rr|r|r|r|r|r|}
\hline \multirow{2}{*}{ Model } & \multicolumn{2}{|c|}{$\begin{array}{c}\text { Unstandardized } \\
\text { Coefficients }\end{array}$} & \multicolumn{2}{c|}{$\begin{array}{c}\text { Standardized } \\
\text { Coefficients }\end{array}$} & & \\
\cline { 3 - 5 } & & \multicolumn{1}{|c|}{$\mathrm{B}$} & \multicolumn{1}{c|}{ Std. Error } & \multicolumn{1}{c|}{ Beta } & \multicolumn{1}{c|}{ S } & Sig. \\
\hline 1 & (Constant) & 7.481 & 1.634 & & 4.579 & .000 \\
& VAR00007 & .912 & .126 & .660 & 7.229 & .000 \\
& VAR00001 & $-1.749 \mathrm{E}-07$ & .000 & -.238 & -1.576 & .119 \\
& VAR00004 & .451 & .134 & .347 & 3.380 & .001 \\
& VAR00006 & $2.664 \mathrm{E}-03$ & .003 & .125 & .898 & .371 \\
\hline
\end{tabular}

a. Dependent Variable: VAR00008

Table IVf: Time Model milestones summary (Cost dependent)

Model Summary

\begin{tabular}{|l|c|r|r|r|}
\hline Model & $\mathrm{R}$ & R Square & $\begin{array}{c}\text { Adjusted } \\
\text { R Square }\end{array}$ & $\begin{array}{r}\text { Std. Error of } \\
\text { the Estimate }\end{array}$ \\
\hline 1 & $.875^{\mathrm{a}}$ & .765 & .754 & 7.91782 \\
\hline
\end{tabular}

a. Predictors: (Constant), VAR00006, VAR00007, VAR00004, VAR00001

With the $R, R^{2}$ and Adjusted $R^{2}$ values are $0.875,0.765$ and 0.754 respectively, obviously the model is both about $75 \%$ fit and strong for reliance with most of the needed elements in reliable order of significance taken at $5 \%$.

From Equation IV above, if the proposed time projected by contractor, the lowest bid (mostly taken as the Successful bid), proposed time projected by consultant and the Gross Floor Area are known, the model can be a useful tool to predict the realistic construction period.

\section{Analysis on Supply Projects}

Unlike the result revealed on the analysis of the data available on construction projects, the analysis on the data available on supplies project used for this study reveals that over $75 \%$ of the projects were delivered with absolute cost performance. However, the Time performance was worse compared to construction projects. Although, supply contracts used to take less time than construction projects, however, only about $7 \%$ were delivered timely. The time variance ranges between -33 and $1,250 \%$. This was not without variance between consultant estimates and actual contract details. Despite ubiquitous 
opportunities given to construction professionals under the Due Process policy in Nigeria to serve as main procurement officers in Nigerian public institutions, there are many evidences in this study portraying the use of traditional construction professionals as procurement officers for other materials not conventional with common construction materials (e.g. complex teaching and research equipment for advanced academic purposes) as a major challenge. In most cases, their judgments are wrong and confusing. A comprehensive report will be given on this in another study. Table $V$ shows a brief of project performance of selected supply projects as defined in this study.

\section{Insert Table V}

Moreover, the correlation analysis of the variables shows that there exist strong relationships between relative variables in the system. Table VI shows the correlation analysis of the variables of the selected supply projects used for the study.

\section{Insert Table VI}

Further analysis reveals that only the Final Cost of Supply projects could be predicted through this model. The model discovered is given thus in Equation 5.

$\mathrm{F}_{\mathrm{s}}=496366.157+0.005796 \mathrm{x}_{1}-0.001430 \mathrm{x}_{2}+0.964 \mathrm{x}_{3} \ldots \ldots$.Equation 5

Where $F_{\mathrm{s}}=$ Final Supply contract cost 


$$
\begin{aligned}
& x_{1}=\text { Average Tender Figure } \\
& x_{2}=\text { Consultant Figure } \\
& x_{3}=\text { Successful bid Figure }
\end{aligned}
$$

In this instance, the $R, R^{2}$ and Adjusted $R^{2}$ values are $0.992,0.983$ and 0.982 respectively, obviously the model is both about $98 \%$ fit and strong for reliance with most of the needed elements in reliable order of significance taken at $5 \%$. Tables $\mathrm{VI}(\mathrm{a})$ and (b) show the summary for the model presented in Equation 5.

Table Vla: Summary of final supply contract cost model variables and

\begin{tabular}{|c|c|c|c|c|c|c|}
\hline \multirow{2}{*}{\multicolumn{2}{|c|}{ Model }} & \multicolumn{2}{|c|}{$\begin{array}{c}\text { Unstandardized } \\
\text { Coefficients }\end{array}$} & \multirow{2}{*}{$\begin{array}{c}\text { Standardized } \\
\text { Coefficients }\end{array}$} & \multirow[b]{2}{*}{$t$} & \multirow[b]{2}{*}{ Sig. } \\
\hline & & $\mathrm{B}$ & Std. Error & & & \\
\hline \multirow[t]{4}{*}{1} & (Constant) & 496366.157 & 240592.832 & & 2.063 & .046 \\
\hline & VAR00002 & 5.796E-03 & .033 & .009 & .177 & .861 \\
\hline & VAR00003 & $-1.430 \mathrm{E}-03$ & .050 & -.001 & -.029 & .977 \\
\hline & VAR00004 & .964 & .064 & .985 & 15.123 & .000 \\
\hline
\end{tabular}
coefficients.

Coefficients

a. Dependent Variable: VAR00005

Table VIb: Supply contract cost Model milestones summary

Model Summary

\begin{tabular}{|l|c|r|r|r|}
\hline Model & $\mathrm{R}$ & R Square & $\begin{array}{c}\text { Adjusted } \\
\text { R Square }\end{array}$ & $\begin{array}{c}\text { Std. Error of } \\
\text { the Estimate }\end{array}$ \\
\hline 1 & $.992^{\mathrm{a}}$ & .983 & .982 & 773732.36808 \\
\hline
\end{tabular}

a. Predictors: (Constant), VAR00004, VAR00003, VAR00002

\section{CONCLUSION}

The challenge posed by cost and time performance of project industry is peculiar. This study has presented a systemic preview of cost and time performance of some selected construction and supply projects in Nigeria. It was discovered that while there is major variance from projected estimate in 
reference to final construction cost, the professional opinions of consultants also show major variance. It was therefore discovered that professionalism instincts still need a lot of improvement in terms of research in relation to effective decision support tools in order to be precise and effectual in their opinions.

While about $45 \%$ of the construction projects were realized within budget, over $75 \%$ of the supply contract were realized within budget. However, only about $7 \%$ of the supply contracts were delivered to time while the variant in reference to project contract period is as wide as -33 to $1,250 \%$. Therefore, a dynamic stochastic general equilibrium model is proposed for predicting the time performance of supply contracts in construction. A number of models were created to predict the final construction cost, the actual contract period for construction projects (time and cost variable based) as well as final contract costs for supply contracts. The degrees of fitness and strength of the models ranged between 75 to $98 \%$.

Based on the foregoing, it is recommended that:

1. Professional institutions in the Nigerian construction industry owe the public a duty of care to use all available mechanism to rise to the challenges of professionalism in the industry.

2. The over-reliance on lowest bid as the main driver of value for money in tender action should no longer be taken as a reliable tool for project performance. Rather, other value mechanics in contractors' competences should be optimized.

3. Modern trends in the direction of motivating construction workers should be focused to such that the few remaining operatives would be encouraged to give their best and encourage others come to the industry in the interest of improving the value image of the industry.

4. Paper-based prequalification has been discovered to be a weak link to a realistic determination of contractor's competences in the construction industry. There should be adequate provisions through effective policy framework to sustain efficient procurement mechanics in the interest of project performance in the industry. 


\section{Recommendation for further studies.}

Based on the issues raised in the study, it is hereby recommended that further studies there should be concerted research efforts on people issues in the construction industry with respect to motivation and incentives to discourage labour attrition in the construction industry. Moreover, it is hereby recommended that there should be further studies on the relationship between paper-based prequalification and contractor's performance in the construction industry.

\section{REFERENCES}

Aibinu A. A and Jagboro G. O (2002): The effects of construction delay on project delivery in Nigerian construction industry. International Journal of Project Management, 20, pp 593 - 599.

Barton Roy T. (2000): Back to Basics - An Overview of Value Management. Proceeding, Hong Kong Institute of Value Management (HKIVM) International Conference. Hong Kong Institute of Value Management.

Bertelson Sven (2003): Construction as a complex system. Proceeding IGLC 11. International Group of Lean Construction $11^{\text {th }}$ Annual Conference July 22 - 24, Virginia Tech, Blacksburg, Virginia, USA

Bjonfot and Stehn (2007) Value Delivery through Product Offers: A Lean Leap in Multi-Storey Timber Housing Construction. Lean Construction Journal 3 (1), pp $33-45$ 
Bresnen, $M$ and Marshall, N (2000): Partnering in construction: a critical review of issues, problems and dilemmas. Construction Management and Economics, 18 (2), pp 229 - 237.

Budget Monitoring and Price Intelligence Unit (BMPIU) (2005): Handbook of Due Process. The Presidency, Abuja, Federal republic of Nigeria.

Chan APC (2001): Time cost relationship of public sector projects in Malaysia. International Journal of Project Management, 19 (4), pp 223-239.

Chan D. W. M, Kumaraswamy M. M. (1999): Modelling and predicting construction durations in Hong Kong public housing. Construction Management and Economics, 17 (3) pp 351 - 362.

Doree, A. G (2004): Collusion in the Dutch Construction Industry. An industrial Organization Perspective. Building Research and Information 32 (2) pp $145-156$

Drew, D.S., Skitmore, R. M., (1990): Analyzing Bidding performance; measuring the influence of contract size and type; Transactions, The International Council for Construction Research Studies and Documentation, CIBW - 65, Sydney, Australia, pp 129 - 139.

Egan, J. (1998): Rethinking Construction, Department of the Environment, Transport and the Regions, London

Elinwa, A. U and Buba, S. A (1993): Construction cost factors in Nigeria. Journal of Construction Engineering Management. 119 (4) pp 698 713. 
Elinwa, A. U and Joshua M (2001): Time overrun factors in the Nigerian construction industry. Journal of Construction Engineering Management. 127 (5), pp $419-425$.

Endut R., Akintoye A and Kelly J (2005): Cost and Time Overrun in construction in Malaysia. Proceedings of the Postgraduate Researchers of the Built Environment (PROBE) Conference, Glasgow Caledonian University, pp 246 - 252.

Gould, N (1998): Alternative dispute resolution in the UK construction industry. In: Hughes, W (Ed.), 14th Annual ARCOM Conference, 9-11 September 1998, University of Reading. Association of Researchers in Construction Management, 2, pp 428-37.

Gorse, C A and Emmitt, S (2004): Management and design team communication. In: Ellis, $\mathrm{R}$ and Bell, $\mathrm{M}$ (Eds.), Proceedings of Construction and Building Research (COBRA) Conference, 7 - 8 September 2004, Leeds Metropolitan University, UK, Royal Institution of Chattered Surveyors (RICS) Foundation.

Gray C (1996): 30\% Real Cost Reduction - the Professional Quantity Surveyor's Role. Proceedings of Construction and Building Research (COBRA) Conference, Royal Institution of Chattered Surveyors (RICS) Foundation.

Gruneberg, S and Hughes, W (2006): Understanding construction consortia: theory, practice and opinions, Royal Institution of Chattered Surveyors (RICS) Research Papers, 6 (1), pp 1 - 53.

Hatush, Z and Skitmore, M R (1997a): Criteria for contractor selection. Construction Management and Economics, 15 (1), pp 19 - 38. 
Hatush, Z and Skitmore, M R (1997b): Evaluating contractor prequalification data: selection criteria and project success factors. Construction Management and Economics, 15 (2), pp 129 - 147.

Ho, M.F.N. and Ng, C. W. V., (2003): Quantity Surveyors' Background and Training, and their Ethical Concepts, Conception and Interests Considerations. Construction Management Economics, 21, pp $43-67$.

Ho Man-Fong, Drew Derek, McGeorge Denny and Martin Loosemore (2004): Implementing corporate ethics management and its comparison with the safety management system: a case study in Hong Kong. Construction Management and Economics, 22, pp 595-606

Holt, G. D., Olomolaiye, P. O. and Harris, F. C. (1994): Factors Influencing UK Construction clients' choice of contractor, Building and Environment, 29 (2), pp $241-248$.

Holt, G. D., Olomolaiye P. O. and Harris, F. C. (1995): A Review of contractor selection practice in the UK Construction Industry. Building and Environment, 30 (4), pp 553 - 561.

Knight, A and Morledge , R (2005): Professionalism and Ethical decision making. Proceedings, Royal Institution of Chartered Surveyors (RICS) Conference. July 4-8, Queensland University of Technology, Brisbane, Australia.

Jackson, S (2002): Project cost overruns and risk management. In: Greenwood, D (Ed.), 18th Annual ARCOM Conference, 2-4 September 2002, University of Northumbria. Association of Researchers in Construction Management, 1, 99 -108. 
Kaka, A. and Price, A. D. F., (1991): Relationship between value and duration of construction projects. Journal of Construction Management and Economics, 9, pp $381-400$.

Kometa, S, Olomolaiye, P and Harris, F (1995): An Evaluation of Clients Needs and Responsibilities in the Construction Process. Engineering, Construction and Architectural Management, 2, (1), pp 57 -76.

Lam, K. C, Hu, T., Ng, S. T, Skitmore, M., Cheung, S. O (2001): A Fuzzy Neural Network Approach for Contractor Prequalification. Construction Management and Economics, 19, pp 175 - 188.

Latham, M (1994): Constructing The Team, Final Report of the Government/Industry Review of Procurement and Contractual Arrangements in the UK Construction Industry, HMSO, London.

Merna, A. and Smith, N. J. (1990): Bid evaluation for UK public sector construction contracts. Proceedings of the Institution Civil Engineers Part I, 88, pp 91-105.

Obiegbu M E (2005): Due Process and the Procurement Methods in the construction industry. Proceeding of the 35th Annual General Meeting / Conference of the Nigerian Institute of Building, Eyimba 2005, $10^{\text {th }}-$ $14^{\text {th }}$ August, pp $23-47$.

Ogunsemi D. R. and Aje I. O. (2005): A Model for Contractors' Selection in Nigeria. The_Nigerian Quantity Surveyor, 9, pp $44-53$.

Okuwoga, A. A. (1998): Cost-time performance of public sector housing projects in Nigeria. Journal of Habitat International, 22 (4) pp 389 395. 
Olatunji O. A. (2006f): Assessing client's confidence and satisfaction in construction professionals in Nigeria. Proceedings of the International Conference on Construction Culture, Innovation and Management. November 17 - 18, Dubai, United Arab Emirate.

Olatunji O. A and Aje I. O (2005c): Eliminating Economic Wastes in Construction Through the Use of Prequalification in Contractor Selection for Construction Projects, Proceedings of the International Conference on Construction and Real Estate (ICCREM 2005), Penang, Malaysia.

Omorwgie A, Obohon O. J, and Radford D (2005): Modelling in ranking procedures: a case study of infrastructure failures in Nigeria. Proceedings of the Postgraduate Researchers of the Built Environment (PROBE) Conference, Glasgow Caledonian, pp 113 124.

Pollington C (1999): Legal procurement practices for sustainable development. Building Research and Information, 27, (2), pp 409 - 411.

Pearl, R., Bowen, P., Makanjee, N., Akintoye A., and Evans K. (2005) Professional Ethics in the South African Construction Industry - a Pilot Study. Proceedings, Royal Institution of Chattered Surveyors (RICS) Conference. July $4-8$, Queensland University of Technology, Brisbane, Australia

Poon J. (2003) Professional ethics for surveyors and construction project performance: what we need to know. Proceedings of Construction and Building Research (COBRA) Conference, Royal Institution of Chattered Surveyors (RICS) Foundation.

Poon, J (2004): The study of ethical perceptions of construction managers. Proceedings of Association of Researchers in Construction 
Management (ARCOM) Conference, Edinburgh, Heriot-Watt University, UK, pp 973 - 983.

Ray, R S, Hornibrook, J, Skitmore, M R and Zarkada-Fraser, A (1999) Ethics in tendering: a survey of Australian opinion and practice. Construction Management and Economics, 17(2), pp 139 - 53.

Ridout, G (1999): Clients say $58 \%$ of jobs finish late. Contract Journal, 14 April, 2.

Salama M, Abd El Aziz H, El Sawah H and El Samadony A (2006): Investigating the criteria for contractors' selection in Egypt. In: Boyd D (Ed) 20th Annual ARCOM Conference, $4-6^{\text {th }}$ September 2006, Birmingham, UK, Association of Researchers in Construction Management, 1, pp 531 - 540.

Scott, J R, Edge, M, Laing, R and Martin, P (2004): Optimising the relationship between passive solar design of new housing and the economics of construction and land value. In: Khosrowshahi, $\mathrm{F}$ (Ed.), 20th Annual ARCOM Conference, 1-3 September 2004, Heriot Watt University. Association of Researchers in Construction Management, .2, pp $1337-1347$.

Smith, S (1998): Stochastic analysis of cyclic construction processes. In: Hughes, W (Ed.), 14th Annual ARCOM Conference, 9-11 September 1998, University of Reading. Association of Researchers in Construction Management, 1, pp 127-136.

Sutrisna, M, Buckley, K, Potts, K and Proverbs, D (2005): A decision support tool for the valuation of variations on civil engineering projects. Royal Institution of Chattered Surveyors (RICS) Research Papers, 5 (7), pp $1-41$. 
Tse, T.C., Wong, K.D and Wong K.W. (2005): The Utilization of Building Information Models in nD Modeling: A Study of Data Interfacing and Adoption Barriers, Electronic Journal of Information Technology in Construction, 10, pp 85 - 110. Available at www.itcon.org/2005/8/

Wahab K A (2005): Due Process, The construction industry and the Builders. Proceeding of the 35th Annual General Meeting/Conference of the Nigerian Institute of Building, Eyimba 2005, 10 - 14 August, pp 63 75 .

Williams, T (2003): Assessing extension of time delays on major projects. International Journal of Project Management, 21, pp $19-26$.

Wong, F W H, Lam, P T I and Chan, A P C (2004): Procurement approaches to achieve better constructability. In: Ellis, $\mathrm{R}$ and Bell, $\mathrm{M}$ (Eds.), Proceedings of Construction and Building Research (COBRA) Conference, 7 - 8 September 2004, Leeds Metropolitan University, UK. Royal Institution of Chattered Surveyors (RICS) RICS Foundation. 


\section{Appendix}

Table I: The breakdown of the professional backgrounds of the respondents

\begin{tabular}{llccc}
\hline S/N & $\begin{array}{l}\text { Professional } \\
\text { Calling }\end{array}$ & $\begin{array}{c}\text { Average Nr } \\
\text { of years of } \\
\text { experience }\end{array}$ & $\begin{array}{c}\text { Nr of Due Process } \\
\text { projects executed } \\
\text { between 2003 and 2005 }\end{array}$ \\
\hline $1 \quad$ Consulting & 5 & 14 & 5 \\
Architect & 2 & 18 & - \\
Engineer & 1 & 14 & - \\
Quantity Surveyors & 1 & 13 & - \\
Builder & 1 & 11 & - \\
Contracting & 4 & 13.25 & - \\
Architect & 1 & 16 & - \\
Engineer & 1 & 12 & - \\
Quantity Surveyor & 1 & 17 & 51 \\
Builder & 1 & 8 & - \\
Civil servants & 4 & 12.75 & - \\
Architect & 1 & 21 & - \\
Engineer & 1 & 12 & \\
Quantity Surveyor & 1 & 10 & - \\
Builder & 1 & 8 & \\
\hline
\end{tabular}

Table II: The breakdown of nature of projects under review between 2003 and 2007

\begin{tabular}{llcc}
\hline S/N & Nature of projects & Number & $\%$ \\
\hline 1 & Building Construction & 56 & 40.88 \\
& New projects & 30 & 21.90 \\
& Rehabilitation & 26 & 18.98 \\
2 & Civil engineering projects & 39 & 28.47 \\
& New road projects & 6 & 4.38 \\
& Road rehabilitation projects & 33 & 24.09 \\
3 & Supplies of equipments & 42 & 30.66 \\
& Library equipments & 5 & 3.65 \\
& Laboratory equipments & 22 & 16.06 \\
& Office equipments & 9 & 6.57 \\
& Household supplies & 6 & 4.38 \\
\hline \multicolumn{2}{c}{ Total } & 137 & 100.00 \\
\hline
\end{tabular}


Table III: Analysis of tender figures and actual contract details (Construction Projects)

\begin{tabular}{|c|c|c|c|c|c|c|c|c|c|c|c|c|c|}
\hline $\mathbf{S} / \mathbf{N}$ & $\begin{array}{l}\text { Year of } \\
\text { Award }\end{array}$ & Figure (Cost) & $\begin{array}{l}\text { Average Bid } \\
\text { Figure }\end{array}$ & $\begin{array}{l}\text { Consultant's } \\
\text { Figure }\end{array}$ & $\begin{array}{l}\text { Proposed Time } \\
\text { of Consultant }\end{array}$ & $\begin{array}{l}\text { Final Contract } \\
\text { Sum }\end{array}$ & $\begin{array}{l}\text { Gross } \\
\text { Floor Area }\end{array}$ & $\begin{array}{l}\text { Proposed } \\
\text { Time of } \\
\text { Contractor } \\
\text { (Weeks) }\end{array}$ & $\begin{array}{l}\text { Actual } \\
\text { Contract } \\
\text { Period } \\
\text { (Weeks) }\end{array}$ & $\begin{array}{l}\% \text { Change } \\
\text { in } \\
\text { Time }\end{array}$ & $\begin{array}{l}\% \text { Change } \\
\text { in } \\
\text { Cost }\end{array}$ & $\begin{array}{l}\text { \% Deviation } \\
\text { from } \\
\text { Consultant's } \\
\text { Figure (Time) }\end{array}$ & $\begin{array}{c}\% \text { Deviation } \\
\text { from } \\
\text { Consultant's } \\
\text { Figure (Cost) }\end{array}$ \\
\hline 1 & 2003 & $11,821,288.50$ & $12,740,654.06$ & $12,020,127.00$ & 28 & $11,075,321.86$ & 572 & 12 & 38 & 216.67 & -6.31 & 35.71 & -7.86 \\
\hline 2 & 2003 & $12,040,512.75$ & $20,573,421.75$ & $20,344,708.12$ & 12 & $11,785,281.26$ & 586 & 12 & 14 & 16.67 & -2.12 & 16.67 & -42.07 \\
\hline 3 & 2003 & $5,443,777.50$ & $6,879,549.18$ & $8,863,469.99$ & 4 & $5,216,907.11$ & 429 & 6 & 16 & 166.67 & -4.17 & 300.00 & -41.14 \\
\hline 4 & 2003 & $18,047,873.99$ & $22,061,926.07$ & $21,057,063.17$ & 28 & $17,821,711.29$ & 752 & 12 & 47 & 291.67 & -1.25 & 67.86 & -15.36 \\
\hline 5 & 2003 & $12,140,550.00$ & $14,281,908.92$ & $13,896,911.28$ & 28 & $11,533,522.50$ & 526 & 12 & 39 & 225 & -5 & 39.29 & -17.01 \\
\hline 6 & 2003 & $8,936,650.00$ & $15,216,826.67$ & $12,692,810.06$ & 20 & $7,517,819.96$ & 324 & 8 & 41 & 412.5 & -15.58 & 105.00 & -40.77 \\
\hline 7 & 2003 & $90,420,605.00$ & $102,821,751.92$ & $98,624,071.26$ & 48 & $88,624,890.00$ & 3,892 & 36 & 78 & 116.67 & -1.99 & 62.50 & -10.14 \\
\hline 8 & 2003 & $40,896,745.00$ & $48,981,361.05$ & $42,847,860.70$ & 38 & $38,700,912.70$ & 1,896 & 36 & 71 & 97.22 & -5.37 & 86.84 & -9.68 \\
\hline 9 & 2003 & $27,309,280.85$ & $29,266,198.87$ & $228,281,907.78$ & 24 & $26,406,920.18$ & 826 & 20 & 36 & 80 & -3.3 & 50.00 & -88.43 \\
\hline 10 & 2003 & $14,737,588.49$ & $18,257,091.65$ & $15,281,962.86$ & 20 & $14,737,586.49$ & 706 & 24 & 40 & 66.67 & 0 & 100.00 & -3.56 \\
\hline 11 & 2003 & $13,055,748.88$ & $13,498,509.21$ & $13,011,388.00$ & 24 & $12,929,945.51$ & 608 & 20 & 36 & 80 & -0.96 & 50.00 & -0.63 \\
\hline 12 & 2003 & $21,691,348.58$ & $27,627,091.02$ & $24,605,091.00$ & 28 & $23,966,741.48$ & 936 & 24 & 42 & 75 & 10.47 & 50.00 & -2.59 \\
\hline 13 & 2003 & $16,892,011.08$ & $21,586,190.86$ & $20,628,196.26$ & 12 & $18,625,197.25$ & 836 & 28 & 30 & 7.14 & 10.26 & 150.00 & -9.71 \\
\hline 14 & 2003 & $18,841,035.00$ & $24,083,217.18$ & $22,352,196.00$ & 18 & $19,327,586.72$ & 857 & 28 & 38 & 35.71 & 2.58 & 111.11 & -13.53 \\
\hline 15 & 2003 & $15,497,905.34$ & $29,306,152.92$ & $26,826,107.00$ & 16 & $13,989,120.87$ & 638 & 8 & 14 & 75 & -9.74 & -12.50 & -47.85 \\
\hline 16 & 2003 & $3,813,220.00$ & $5,829,310.38$ & $5,200,000.00$ & 4 & $4,314,720.00$ & 386 & 4 & 3 & -25 & 13.15 & -25.00 & -17.02 \\
\hline 17 & 2003 & $9,965,190.00$ & $12,081,817.02$ & $9,261,857.00$ & 6 & $8,842,319.88$ & 484 & 4 & 14 & 250 & -11.27 & 133.33 & -4.53 \\
\hline 18 & 2003 & $16,985,808.50$ & $18,286,012.91$ & $15,806,926.85$ & 12 & $15,796,892.17$ & 722 & 8 & 12 & 50 & -7 & 0.00 & -0.06 \\
\hline 19 & 2003 & $4,662,919.50$ & $9,206,101.06$ & $8,701,306.05$ & 12 & $6,096,926.07$ & 438 & 6 & 14 & 133.33 & 30.75 & 16.67 & -29.93 \\
\hline 20 & 2003 & $5,174,081.85$ & $6,128,817.71$ & $5,856,031.00$ & 4 & $4,842,928.96$ & 394 & 4 & 16 & 300 & -6.4 & 300.00 & -17.30 \\
\hline 21 & 2004 & $2,500,000.00$ & $3,156,091.56$ & $2,800,036.00$ & 4 & $2,560,920.36$ & 124 & 4 & 4 & 0 & 2.44 & 0.00 & -8.54 \\
\hline 22 & 2004 & $4,300,732.80$ & $8,019,206.12$ & $5,628,087.00$ & 4 & $4,075,381.97$ & 196 & 4 & 4 & 0 & -5.44 & 0.00 & -27.59 \\
\hline 23 & 2004 & $13,613,284.03$ & $13,890,306.06$ & $13,083,588.50$ & 16 & $12,755,842.28$ & 686 & 6 & 20 & 233.33 & -6.3 & 25.00 & -2.51 \\
\hline 24 & 2004 & $8,409,261.00$ & $13,206,517.00$ & $13,087,528.17$ & 22 & $8,958,924.67$ & 436 & 6 & 18 & 200 & 6.54 & -18.18 & -31.55 \\
\hline 25 & 2004 & $3,165,750.00$ & $3,665,218.80$ & $3,186,509.26$ & 6 & $3,007,462.05$ & 138 & 4 & 12 & 200 & -5 & 100.00 & -5.62 \\
\hline 26 & 2004 & $16,812,011.08$ & $18,827,715.13$ & $16,827,900.00$ & 10 & $15,722,856.08$ & 688 & 8 & 6 & -25 & -6.48 & -40.00 & -6.57 \\
\hline 27 & 2004 & $4,313,220.20$ & $6,282,906.07$ & $4,267,120.00$ & 4 & $3,926,891.63$ & 176 & 4 & 14 & 250 & -8.96 & 250.00 & -7.97 \\
\hline 28 & 2004 & $4,276,177.50$ & $5,602,307.18$ & $4,826,906.00$ & 4 & $4,106,809.28$ & 206 & 4 & 10 & 250 & -3.96 & 150.00 & -14.92 \\
\hline 29 & 2004 & $18,073,364.40$ & $21,067,002.32$ & $18,900,627.00$ & 18 & $18,073,364.40$ & 857 & 12 & 18 & 50 & 0 & 0.00 & -4.38 \\
\hline
\end{tabular}




$\begin{array}{rrrrr}30 & 2004 & 17,212,728.00 & 28,326,051.30 & 24,084,250.00 \\ 31 & 2004 & 4,972,301.39 & 7,201,096.38 & 5,263,081.50 \\ 32 & 2004 & 2,708,398.00 & 2,961,326.96 & 352,305,700.00 \\ 33 & 2004 & 5,825,312.05 & 9,462,817.03 & 9,096,613.00 \\ 34 & 2004 & 15,719,502.51 & 24,503,831.05 & 24,370,812.00 \\ 35 & 2004 & 81,422,709.00 & 90,118,015.93 & 91,700,662.67 \\ 36 & 2004 & 28,300,398.39 & 48,925,421.01 & 50,436,220.50 \\ 37 & 2004 & 18,364,907.80 & 30,603,812.00 & 28,688,073.81 \\ 38 & 2004 & 9,857,650.96 & 19,400,625.25 & 15,218,177.08 \\ 39 & 2004 & 23,128,352.01 & 43,931,478.90 & 40,126,301.39 \\ 40 & 2004 & 42,092,928.00 & 45,203,555.00 & 46,340,241.67 \\ 41 & 2005 & 90,628,892.63 & 95,924,809.29 & 92,491,357.01 \\ 42 & 2005 & 16,267,106.28 & 20,628,174.82 & 22,583,225.00 \\ 43 & 2005 & 4,406,755.67 & 10,888,924.00 & 10,681,318.00 \\ 44 & 2005 & 8,055,926.50 & 15,900,810.01 & 16,128,364.18 \\ 45 & 2005 & 89,261,817.71 & 105,891,057.81 & 100,910,813.00 \\ 46 & 2005 & 13,083,120.00 & 32,523,081.07 & 30,414,300.82 \\ 47 & 2005 & 17,929,171.81 & 23,989,192.15 & 22,582,510.40 \\ 48 & 2005 & 28,692,452.00 & 40,311,500.00 & 42,355,750.20 \\ 49 & 2005 & 43,310,230.01 & 55,230,381.67 & 55,982,313.81 \\ 50 & 2005 & 32,497,888.30 & 49,032,266.82 & 50,010,212.80 \\ 51 & 2005 & 12,522,306.03 & 25,300,863.43 & 24,555,982.15 \\ 52 & 2005 & 17,183,980.52 & 17,310,920.00 & 18,209,474.00 \\ 53 & 2005 & 53,200,320.00 & 54,500,720.00 & 54,061,561.00 \\ 54 & 2005 & 50,841,856.41 & 50,999,827.68 & 49,268,430.08 \\ 55 & 2005 & 18,821,605.02 & 19,632,451.03 & 20,782,125.13 \\ 56 & 2005 & 20,700,278.20 & 23,432,156.08 & 19,778,489.00 \\ 57 & 2005 & 5,280,778.08 & 7,000,290.00 & 6,125,892.07 \\ 58 & 2005 & 15,589,662.50 & 15,799,978.78 & 13,281,092.73 \\ 59 & 2005 & 60,288,185.20 & 63,158,290.00 & 61,092,117.95 \\ 60 & 2005 & 68,300,189.57 & 69,291,787.79 & 66,982,829.29 \\ 61 & 2006 & 2,809,661.00 & 3,982,772.02 & 2,500,550.98 \\ 62 & 2006 & 48,198,781.00 & 49,289,112.00 & 48,329,036.66 \\ 63 & 2006 & 58,120,299.02 & 59,789,999.78 & 59,025,827.10 \\ 64 & 2006 & 12,128,129.02 & 15,927,589.92 & 13,568,791.17 \\ 65 & 2006 & 45,790,162.58 & 48,290,168.62 & 47,089,288.74\end{array}$

$\begin{array}{rcc}19,209,809.50 & 872 & 12 \\ 4,806,907.80 & 218 & 4 \\ 2,708,500.00 & 126 & 4 \\ 8,205,381.01 & 302 & 6 \\ 21,871,400.03 & 821 & 18 \\ 85,789,125.04 & 900 & 38 \\ 4,303,410.00 & 1,724 & 30 \\ 25,700,821.00 & 543 & 20 \\ 13,219,513.54 & 482 & 8 \\ 37,200,000.10 & 952 & 30 \\ 42,541,032.00 & 1,534 & 24 \\ 90,663,371.18 & 2,828 & 37 \\ 20,907,389.42 & 842 & 18 \\ 8,762,310.80 & 289 & 8 \\ 12,924,531.92 & 400 & 9 \\ 96,500,412.00 & 2,936 & 43 \\ 27,612,511.82 & 501 & 17 \\ 19,457,980.00 & 782 & 11 \\ 42,128,422.71 & 1,500 & 22 \\ 55,601,235.43 & 2,157 & 24 \\ 49,081,874.50 & 1,802 & 21 \\ 24,310,371.00 & 934 & 15 \\ 16,430,810.00 & 608 & 10 \\ 52,021,940.01 & 2,060 & 30 \\ 49,100,800.00 & 1,859 & 25 \\ 18,391,932.45 & 702 & 14 \\ 21,578,299.15 & 890 & 28 \\ 6,992,615.01 & 279 & 8 \\ 15,302,128.29 & 603 & 12 \\ 63,329,750.72 & 2,510 & 38 \\ 65,779,520.00 & 2,438 & 36 \\ 3,252,257.90 & 130 & 12 \\ 49,128,577.00 & 1,872 & 42 \\ 58,750,290.89 & 1,857 & 52 \\ 14,160,028.29 & 500 & 24 \\ 46,275,985.00 & 1,843 & 52 \\ & & \end{array}$

$\begin{array}{ccccc}20 & 66.67 & 11.6 & 11.11 & -20.24 \\ 6 & 50 & -3.33 & 50.00 & -8.67 \\ 8 & 100 & 0 & 166.67 & -99.23 \\ 12 & 100 & 40.86 & 200.00 & -9.80 \\ 24 & 33.33 & 39.14 & 20.00 & -10.26 \\ 56 & 47.37 & 5.36 & 40.00 & -6.45 \\ 50 & 66.67 & -84.79 & 61.29 & -91.47 \\ 41 & 105 & 39.95 & 127.78 & -10.41 \\ 19 & 137.5 & 34.1 & 216.67 & -13.13 \\ 43 & 43.33 & 60.84 & 53.57 & -7.29 \\ 44 & 83.33 & 1.06 & 76.00 & -8.20 \\ 55 & 48.65 & 0.04 & 44.74 & -1.98 \\ 34 & 88.89 & 28.53 & 126.67 & -7.42 \\ 19 & 137.5 & 98.84 & 216.67 & -17.97 \\ 20 & 122.22 & 60.44 & 150.00 & -19.86 \\ 56 & 30.33 & 8.11 & 33.33 & -4.37 \\ 26 & 52.94 & 111.05 & 73.33 & -9.21 \\ 30 & 172.32 & 8.53 & 200.00 & -13.84 \\ 40 & 81.81 & 46.83 & 90.48 & -0.54 \\ 35 & 45.83 & 28.38 & 52.17 & -0.68 \\ 42 & 100 & 51.03 & 90.91 & -1.86 \\ 34 & 126.67 & 94.14 & 142.86 & -1.00 \\ 20 & 100 & -4.38 & 122.22 & -9.77 \\ 48 & 60 & -2.21 & 71.43 & -3.77 \\ 37 & 48 & -3.42 & 60.87 & -0.34 \\ 29 & 107.14 & -2.28 & 141.67 & -11.50 \\ 58 & 107.14 & 4.24 & 190.00 & 9.10 \\ 20 & 150 & 32.42 & 400.00 & 14.15 \\ 24 & 100 & -1.84 & 100.00 & 15.22 \\ 40 & 5.26 & 5.05 & 17.65 & 3.66 \\ 40 & 11.11 & -3.69 & 17.65 & -1.80 \\ 24 & 100 & 15.75 & 500.00 & 30.06 \\ 48 & 14.29 & 1.93 & 60.00 & 1.65 \\ 62 & 19.23 & 1.08 & 29.17 & -0.47 \\ 30 & 25 & 16.75 & 150.00 & 4.36 \\ 60 & 15.38 & 1.06 & 25.00 & -1.73\end{array}$




\begin{tabular}{|c|c|c|c|c|c|c|c|c|c|c|c|c|c|}
\hline 66 & 2006 & $16,178,189.78$ & $16,790,758.52$ & $15,690,786.29$ & 25 & $16,579,028.57$ & 672 & 28 & 38 & 35.71 & 2.48 & 52.00 & 5.66 \\
\hline 67 & 2006 & $5,679,802.91$ & $7,168,370.82$ & $6,224,486.00$ & 4 & 7,025,588.95 & 254 & 6 & 8 & 33.33 & 23.69 & 100.00 & 12.87 \\
\hline 68 & 2006 & $15,989,950.62$ & $19,779,543.13$ & $17,625,789.03$ & 16 & $16,159,786.86$ & 600 & 22 & 32 & 45.45 & 1.06 & 100.00 & -8.32 \\
\hline 69 & 2006 & $17,182,288.79$ & $18,200,788.00$ & $17,502,788.79$ & 16 & $18,592,661.92$ & 764 & 22 & 32 & 45.45 & 8.21 & 100.00 & 6.23 \\
\hline 70 & 2006 & $6,152,826.00$ & $6,980,350.15$ & $6,570,290.34$ & 5 & $6,790,290.13$ & 264 & 8 & 12 & 50 & 10.36 & 140.00 & 3.35 \\
\hline 71 & 2006 & $7,831,232.82$ & $9,682,743.05$ & $8,556,921.82$ & 15 & $6,457,321.82$ & 264 & 10 & 18 & 80 & 17.54 & 20.00 & -24.54 \\
\hline 72 & 2006 & $9,420,467.43$ & $11,642,385.62$ & $10,113,002.00$ & 23 & $7,322,010.72$ & 283 & 20 & 38 & 90 & 22.28 & 65.22 & -27.60 \\
\hline 73 & 2006 & $15,583,628.58$ & $17,092,641.48$ & $17,082,654.83$ & 12 & $12,842,820.81$ & 500 & 18 & 40 & 122.22 & -17.59 & 233.33 & -24.82 \\
\hline 74 & 2006 & $38,241,927.61$ & $43,826,450.28$ & $42,946,857.50$ & 30 & $25,671,676.56$ & 1,123 & 24 & 43 & 79.19 & -32.87 & 43.33 & -40.22 \\
\hline 75 & 2006 & $3,973,643.08$ & $6,571,241.87$ & $5,781,469.46$ & 10 & $3,964,521.33$ & 146 & 6 & 12 & 100 & -0.23 & 20.00 & -31.43 \\
\hline 76 & 2006 & $18,821,653.23$ & $21,284,600.00$ & $20,543,876.21$ & 14 & $16,702,893.40$ & 653 & 8 & 16 & 100 & -11.26 & 14.29 & -18.70 \\
\hline 77 & 2006 & $42,546,298.29$ & $46,082,491.00$ & $44,289,531.81$ & 22 & $40,826,134.28$ & 1,532 & 18 & 29 & 61.11 & -4.04 & 31.82 & -7.82 \\
\hline 78 & 2006 & $2,692,107.48$ & $5,225,341.00$ & $4,673,928.22$ & 8 & $4,343,280.21$ & 187 & 10 & 30 & 200 & 61.33 & 275.00 & -7.07 \\
\hline 79 & 2006 & $10,287,345.35$ & $15,536,489.80$ & $13,189,450.20$ & 10 & $12,112,354.00$ & 462 & 8 & 32 & 300 & 17.74 & 220.00 & -8.17 \\
\hline 80 & 2006 & $19,107,843.74$ & $27,972,456.43$ & $25,064,373.00$ & 12 & $24,103,896.26$ & 963 & 16 & 24 & 50 & 26.15 & 100.00 & -3.83 \\
\hline 81 & 2007 & $23,091,546.00$ & $26,645,803.26$ & $2,634,056.33$ & 24 & $23,934,685.58$ & 923 & 20 & 47 & 135 & 3.65 & 95.83 & 808.66 \\
\hline 82 & 2007 & $16,323,890.00$ & $18,236,847.01$ & $18,113,664.23$ & 20 & $15,466,600.04$ & 594 & 18 & 38 & 111.11 & -5.25 & 90.00 & -14.61 \\
\hline 83 & 2007 & $51,721,500.02$ & $53,749,522.86$ & $50,682,773.51$ & 32 & $42,238,502.03$ & 1,429 & 28 & 52 & 85.71 & -18.33 & 62.50 & -16.66 \\
\hline 84 & 2007 & $40,042,340.53$ & $42,826,711.24$ & $41,117,881.00$ & 48 & $32,652,113.00$ & 1,200 & 40 & 60 & 50 & -18.46 & 25.00 & -20.59 \\
\hline 85 & 2007 & $4,891,621.34$ & $9,126,847.03$ & $10,020,345.80$ & 14 & $6,157,820.44$ & 254 & 10 & 30 & 200 & 25.89 & 114.29 & -38.55 \\
\hline 86 & 2007 & $12,586,100.46$ & $15,956,810.11$ & $17,600,893.40$ & 10 & $17,401,021.53$ & 682 & 6 & 18 & 200 & 38.26 & 80.00 & -1.14 \\
\hline 87 & 2007 & $20,921,102.25$ & $22,701,020.06$ & $23,500,467.32$ & 18 & $20,570,582.31$ & 800 & 10 & 25 & 150 & -1.68 & 38.89 & -12.47 \\
\hline 88 & 2007 & $32,148,659.81$ & $35,842,512.75$ & $34,285,540.58$ & 29 & $32,923,845.82$ & 1,200 & 20 & 42 & 110 & 2.41 & 44.83 & -3.97 \\
\hline 89 & 2007 & $18,357,826.02$ & $20,249,288.00$ & $18,386,621.34$ & 28 & $1,542,869.00$ & 612 & 30 & 43 & 43.33 & -91.6 & 53.57 & -91.61 \\
\hline 90 & 2007 & $8,942,500.00$ & $12,333,434.00$ & $14,422,167.00$ & 40 & $10,658,924.00$ & 426 & 35 & 50 & 42.86 & 19.19 & 25.00 & -26.09 \\
\hline 91 & 2007 & $25,084,062.00$ & $28,083,091.91$ & $26,789,134.54$ & 22 & 26,922,238.82 & 868 & 20 & 38 & 90 & 7.33 & 72.73 & 0.50 \\
\hline 92 & 2007 & $53,989,761.73$ & $59,783,291.79$ & $57,167,240.29$ & 30 & $54,378,035.50$ & 2,105 & 28 & 32 & 14.29 & 0,72 & 6.67 & -4.88 \\
\hline 93 & 2007 & $2,250,071.71$ & $5,168,092.20$ & $3,303,549.34$ & 4 & $4,522,784.42$ & 208 & 6 & 12 & 100 & 101.1 & 200.00 & 36.91 \\
\hline 94 & 2007 & $4,281,489.98$ & $5,550,098.00$ & $5,130,680.00$ & 5 & $3,789,285.00$ & 148 & 8 & 14 & 75 & -11.5 & 180.00 & -26.14 \\
\hline 95 & 2007 & $89,900,180.92$ & $97,920,083.80$ & $92,574,323.29$ & 52 & $95,280,031.32$ & 3,004 & 50 & 68 & 36 & 5.98 & 30.77 & 2.92 \\
\hline
\end{tabular}


Table IV: Correlation Analysis of Variables (Pearson)

Correlations

\begin{tabular}{|c|c|c|c|c|c|c|c|c|c|c|c|c|c|}
\hline & & VAR00001 & VAR00002 & VAR00003 & VAR00004 & VAR00005 & VAR00006 & VAR00007 & VAR00008 & VAR00009 & VAR00010 & VAR00011 & VAR00012 \\
\hline \multirow[t]{3}{*}{ VAR00001 } & Pearson Correlation & 1 & $.981^{\star \star}$ & $.427^{\star \star}$ & $.809^{* \star}$ & $.971^{\star \star}$ & $.928^{\star \prime}$ & $.747^{\star \star}$ & $.652^{* \star}$ & $-.346^{\star \star}$ & -.192 & $-.378^{\star}$ & .038 \\
\hline & Sig. (2-tailed) & & .000 & .000 & .000 & .000 & .000 & .000 & .000 & .001 & .064 & .000 & .712 \\
\hline & $\mathrm{N}$ & 95 & 95 & 95 & 95 & 95 & 95 & 95 & 95 & 95 & 94 & 95 & 95 \\
\hline \multirow[t]{3}{*}{ VAR00002 } & Pearson Correlation & $.981^{\star \star}$ & 1 & $.421^{\star \star}$ & $.802^{\star \star}$ & $.970^{\star \star}$ & $.931^{\star}$ & $.742^{\star \star}$ & $.662^{\star \star}$ & $-.345^{\star \star}$ & -.114 & $-.378^{\star x}$ & .024 \\
\hline & Sig. (2-tailed) & .000 & . & .000 & .000 & .000 & .000 & .000 & .000 & .001 & .276 & .000 & .814 \\
\hline & $\mathrm{N}$ & 95 & 95 & 95 & 95 & 95 & 95 & 95 & 95 & 95 & 94 & 95 & 95 \\
\hline \multirow[t]{3}{*}{ VAR00003 } & Pearson Correlation & $.427^{* \star}$ & $.421^{\star \star}$ & 1 & $.314^{\star \star}$ & $.418^{\star \star}$ & $.378^{\star x}$ & $.288^{\star \star}$ & $.230^{*}$ & -.185 & -.101 & -.145 & -.173 \\
\hline & Sig. (2-tailed) & .000 & .000 & & .002 & .000 & .000 & .005 & .025 & .072 & .335 & .161 & .093 \\
\hline & $\mathrm{N}$ & 95 & 95 & 95 & 95 & 95 & 95 & 95 & 95 & 95 & 94 & 95 & 95 \\
\hline \multirow[t]{3}{*}{ VAR00004 } & Pearson Correlation & $.809^{\star \star}$ & $.802^{\star \star}$ & $.314^{\star \star}$ & 1 & $.758^{\star \star}$ & $.767^{\star \star}$ & $.813^{\star \star}$ & $.788^{\star \star}$ & $-.261^{*}$ & $-.256^{\star}$ & $-.523^{\star \star}$ & .039 \\
\hline & Sig. (2-tailed) & .000 & .000 & .002 & & .000 & .000 & .000 & .000 & .011 & .013 & .000 & .706 \\
\hline & $\mathrm{N}$ & 95 & 95 & 95 & 95 & 95 & 95 & 95 & 95 & 95 & 94 & 95 & 95 \\
\hline \multirow[t]{3}{*}{ VAR00005 } & Pearson Correlation & $.971^{\star \star}$ & $.970^{\star \star}$ & $.418^{\star \star}$ & $.758^{\star \star}$ & 1 & $.911^{\star}$ & $.719^{\star \star}$ & $.620^{\star \star}$ & $-.343^{\star \star}$ & .006 & $-.344^{\star \star}$ & .066 \\
\hline & Sig. (2-tailed) & .000 & .000 & .000 & .000 & & .000 & .000 & .000 & .001 & .955 & .001 & .525 \\
\hline & $\mathrm{N}$ & 95 & 95 & 95 & 95 & 95 & 95 & 95 & 95 & 95 & 94 & 95 & 95 \\
\hline \multirow[t]{3}{*}{ VAR00006 } & Pearson Correlation & $.928^{\star *}$ & $.931^{\star \star}$ & $.378^{\star \star}$ & $.767^{\star \star}$ & $.911^{\star \star}$ & 1 & $.725^{\star \star}$ & $.649^{\star \star}$ & $-.332^{\star \star}$ & -.148 & $-.361^{*}$ & .042 \\
\hline & Sig. (2-tailed) & .000 & .000 & .000 & .000 & .000 & & .000 & .000 & .001 & .154 & .000 & .685 \\
\hline & $\mathrm{N}$ & 95 & 95 & 95 & 95 & 95 & 95 & 95 & 95 & 95 & 94 & 95 & 95 \\
\hline \multirow[t]{3}{*}{ VAR00007 } & Pearson Correlation & $.747^{\star \star}$ & $.742^{\star \star}$ & $.288^{\star \star}$ & $.813^{\star \star}$ & $.719^{\star \star}$ & $.725^{\star}$ & 1 & $.856^{\star \star}$ & $-.469^{\star \star}$ & -.157 & $-.260^{*}$ & .046 \\
\hline & Sig. (2-tailed) & .000 & .000 & .005 & .000 & .000 & .000 & & .000 & .000 & .130 & .011 & .655 \\
\hline & $\mathrm{N}$ & 95 & 95 & 95 & 95 & 95 & 95 & 95 & 95 & 95 & 94 & 95 & 95 \\
\hline \multirow[t]{3}{*}{ VAR00008 } & Pearson Correlation & $.652^{* *}$ & $.662^{\star \star}$ & $.230^{*}$ & $.788^{\star \star}$ & $.620^{* \star}$ & $.649^{*}$ & $.856^{\star \star}$ & 1 & -.068 & -.154 & -.106 & .115 \\
\hline & Sig. (2-tailed) & .000 & .000 & .025 & .000 & .000 & .000 & .000 & & .511 & .139 & .309 & .265 \\
\hline & $\mathrm{N}$ & 95 & 95 & 95 & 95 & 95 & 95 & 95 & 95 & 95 & 94 & 95 & 95 \\
\hline \multirow[t]{3}{*}{ VAR00009 } & Pearson Correlation & $-.346^{* \star}$ & $-.345^{\star \star}$ & -.185 & $-.261^{*}$ & $-.343^{\star \star}$ & $-.332^{*}$ & $-.469^{\star \star}$ & -.068 & 1 & .012 & $.409^{* \star}$ & .023 \\
\hline & Sig. (2-tailed) & .001 & .001 & .072 & .011 & .001 & .001 & .000 & .511 & & .910 & .000 & .825 \\
\hline & $\mathrm{N}$ & 95 & 95 & 95 & 95 & 95 & 95 & 95 & 95 & 95 & 94 & 95 & 95 \\
\hline \multirow[t]{3}{*}{ VAR00010 } & Pearson Correlation & -.192 & -.114 & -.101 & $-.256^{*}$ & .006 & -.148 & -.157 & -.154 & .012 & 1 & $.250^{*}$ & .090 \\
\hline & Sig. (2-tailed) & .064 & .276 & .335 & .013 & .955 & .154 & .130 & .139 & .910 & & .015 & .387 \\
\hline & & 94 & 94 & 94 & 94 & 94 & 94 & 94 & 94 & 94 & 94 & 94 & 94 \\
\hline \multirow[t]{3}{*}{ VAR00011 } & & & & -.145 & $-.523^{\star \star}$ & $-.344^{\star \star}$ & $-.361^{\star \prime}$ & $-.260^{*}$ & -.106 & $.409^{* \star}$ & $.250^{*}$ & 1 & .046 \\
\hline & Sig. (2-tailed) & .000 & .000 & .161 & .000 & .001 & .000 & .011 & .309 & .000 & .015 & . & .656 \\
\hline & $\mathrm{N}$ & 95 & 95 & 95 & 95 & 95 & 95 & 95 & 95 & 95 & 94 & 95 & 95 \\
\hline \multirow[t]{3}{*}{ VAR00012 } & Pearson Correlation & .038 & .024 & -.173 & .039 & .066 & .042 & .046 & .115 & .023 & .090 & .046 & 1 \\
\hline & Sig. (2-tailed) & .712 & .814 & .093 & .706 & .525 & .685 & .655 & .265 & .825 & .387 & .656 & \\
\hline & $\mathrm{N}$ & 95 & 95 & 95 & 95 & 95 & 95 & 95 & 95 & 95 & 94 & 95 & 95 \\
\hline
\end{tabular}

${ }^{* *}$. Correlation is significant at the 0.01 level (2-tailed).

*. Correlation is significant at the 0.05 level (2-tailed). 
Correlations

\begin{tabular}{|c|c|c|c|c|c|c|c|c|c|c|c|c|c|c|}
\hline \multirow{37}{*}{ Spearman's rho } & \multirow{4}{*}{ VAR00001 } & \multirow{4}{*}{$\begin{array}{l}\text { Correlation Coefficient } \\
\text { Sig. (2-tailed) } \\
\text { N }\end{array}$} & \multirow{3}{*}{$\begin{array}{r}\text { VAR00001 } \\
1.000\end{array}$} & VAR00002 & VAR00003 & VAR00004 & VAR00005 & VAR00006 & VAR00007 & VAR00008 & VAR00009 & \multirow{2}{*}{$\begin{array}{l}\text { VAR00010 } \\
-152\end{array}$} & VAR00011 & \multirow{2}{*}{$\frac{\text { VAR00012 }}{.266^{*}}$} \\
\hline & & & & $.959^{\star *}$ & $.867^{\star \star}$ & $.823^{\star \star}$ & $.917^{\star \star}$ & $.958^{\star \star}$ & $.809^{\star \star x}$ & $.719^{\star \star}$ & $-.365^{\star \star}$ & & $-.358^{\star \star}$ & \\
\hline & & & & .000 & .000 & .000 & .000 & .000 & .000 & .000 & .000 & .145 & .000 & .009 \\
\hline & & & 95 & 95 & 95 & 95 & 95 & 95 & 95 & 95 & 95 & 94 & 95 & 95 \\
\hline & \multirow[t]{3}{*}{ VAR00002 } & Correlation Coefficient & $.959^{\star \star}$ & 1.000 & $.900^{\star \star *}$ & $.803^{\star *}$ & $.930^{* *}$ & $.947^{\star \star}$ & $.796^{* *}$ & $.696^{\star *}$ & $-.383^{\star *}$ & -.035 & $-.367^{\star *}$ & .200 \\
\hline & & Sig. (2-tailed) & .000 & & .000 & .000 & .000 & .000 & .000 & .000 & .000 & .737 & .000 & .052 \\
\hline & & $\mathrm{N}$ & 95 & 95 & 95 & 95 & 95 & 95 & 95 & 95 & 95 & 94 & 95 & 95 \\
\hline & \multirow[t]{3}{*}{ VAR00003 } & Correlation Coefficient & $.867 * \star$ & $.900 * x$ & 1.000 & $.713^{\star \star}$ & $.840 * \star$ & $.848^{\star \star \star}$ & $.714^{\star \star}$ & $.605 * \star$ & $-.364^{\star \star}$ & -.044 & $-.316^{* \star}$ & .055 \\
\hline & & Sig. (2-tailed) & .000 & .000 & & .000 & .000 & .000 & .000 & .000 & .000 & .677 & .002 & .593 \\
\hline & & $\mathrm{N}$ & 95 & 95 & 95 & 95 & 95 & 95 & 95 & 95 & 95 & 94 & 95 & 95 \\
\hline & \multirow[t]{3}{*}{ VAR00004 } & Correlation Coefficient & $.823 * *$ & $.803^{\star \star *}$ & $.713^{* \star}$ & 1.000 & $.731^{\star \star}$ & $.794^{\star \star *}$ & $.835 * *$ & $.828 * *$ & $-.292^{\star \star}$ & -.148 & $-.500 * *$ & .103 \\
\hline & & Sig. (2-tailed) & .000 & .000 & .000 & & .000 & .000 & .000 & .000 & .004 & .153 & .000 & 320 \\
\hline & & $\mathrm{N}$ & 95 & 95 & 95 & 95 & 95 & 95 & 95 & 95 & 95 & 94 & 95 & 95 \\
\hline & \multirow[t]{3}{*}{ VAR00005 } & Correlation Coefficient & $.917^{* \star}$ & $.930^{* *}$ & $.840 * \star \mid$ & $.731 * \star$ & 1.000 & $.915^{\star \star *}$ & $.744^{\star \star *}$ & $.647 * *$ & $-.334^{\star \star}$ & .113 & $-.289 * *$ & $.378^{*}$ \\
\hline & & Sig. (2-tailed) & .000 & .000 & .000 & .000 & & .000 & .000 & .000 & .001 & 278 & .005 & .000 \\
\hline & & $\mathrm{N}$ & 95 & 95 & 95 & 95 & 95 & 95 & 95 & 95 & 95 & 94 & 95 & 95 \\
\hline & \multirow[t]{3}{*}{ VAR00006 } & Correlation Coefficient & $.958 * \star$ & $.947^{* \star}$ & $.848^{\star \star *}$ & $.794 * \star$ & $.915^{\star \star}$ & 1.000 & $.782^{\star \star x}$ & $.682^{\star \star}$ & $-.363^{\star \star}$ & -.067 & $-361 * \star \mid$ & $316^{*}$ \\
\hline & & Sig. (2-tailed) & .000 & .000 & .000 & .000 & .000 & & .000 & .000 & .000 & .521 & .000 & .002 \\
\hline & & $\mathrm{N}$ & 95 & 95 & 95 & 95 & 95 & 95 & 95 & 95 & 95 & 94 & 95 & 95 \\
\hline & \multirow{3}{*}{ VAR00007 } & Correlation Coefficient & $.809^{\star \star}$ & $.796 * \star$ & $.714^{\star \star}$ & $.835^{\star \star}$ & $.744^{\star \star}$ & $.782^{\star \star x}$ & 1.000 & .881 ** & $-.477^{\star *}$ & .047 & -.177 & $.271^{*}$ \\
\hline & & Sig. (2-tailed) & .000 & .000 & .000 & .000 & .000 & .000 & & .000 & .000 & .655 & .087 & .008 \\
\hline & & $\mathrm{N}$ & 95 & 95 & 95 & 95 & 95 & 95 & 95 & 95 & 95 & 94 & 95 & 95 \\
\hline & \multirow[t]{3}{*}{ VAR00008 } & Correlation Coefficient & $.719^{\star \star *}$ & $.696^{\star *}$ & $.605^{\star \star}$ & $.828^{\star \star *}$ & $.647^{\star \star}$ & $.682^{* *}$ & $.881^{* *}$ & 1.000 & -.086 & -.012 & -.019 & .170 \\
\hline & & Sig. (2-tailed) & .000 & .000 & .000 & .000 & .000 & .000 & .000 & & .405 & .912 & .857 & .100 \\
\hline & & $\mathrm{N}$ & 95 & 95 & 95 & 95 & 95 & 95 & 95 & 95 & 95 & 94 & 95 & 95 \\
\hline & \multirow[t]{3}{*}{ VAR00009 } & Correlation Coefficient & $-.365^{\star \star}$ & $-.383^{\star \star}$ & $-.364^{\star \star}$ & $-.292^{\star \star}$ & $-.334^{\star \star}$ & $-.363^{\star \star}$ & $-.477^{* *}$ & -.086 & 1.000 & -.049 & $.509 * *$ & $-.207^{*}$ \\
\hline & & Sig. (2-tailed) & .000 & .000 & .000 & .004 & .001 & .000 & .000 & .405 & & .636 & .000 & .044 \\
\hline & & $\mathrm{N}$ & 95 & 95 & 95 & 95 & 95 & 95 & 95 & 95 & 95 & 94 & 95 & 95 \\
\hline & VAR00010 & Correlation Coefficient & -.152 & -.035 & -.044 & -.148 & .113 & -.067 & .047 & -.012 & -.049 & 1.000 & $.238^{*}$ & $.314^{\star}$ \\
\hline & & Sig. (2-tailed) & .145 & .737 & .677 & .153 & 278 & .521 & .655 & .912 & .636 & & .021 & .002 \\
\hline & & $\mathrm{N}$ & 94 & 94 & 94 & 94 & 94 & 94 & 94 & 94 & 94 & 94 & 94 & 94 \\
\hline & VAR00011 & Correlation Coefficient & $-.358^{\star \star}$ & $-.367^{\star \star}$ & $-.316^{\star \star}$ & $-.500^{\star \star}$ & $-.289^{\star \star}$ & $-.361^{\star \star}$ & -.177 & -.019 & $.509 * x$ & $.238^{*}$ & 1.000 & .103 \\
\hline & & Sig. (2-tailed) & .000 & .000 & .002 & .000 & .005 & .000 & .087 & .857 & .000 & .021 & & 319 \\
\hline & & N & 95 & 95 & 95 & 95 & 95 & 95 & 95 & 95 & 95 & 94 & 95 & 95 \\
\hline & VAR00012 & Correlation Coefficient & $.266 * *$ & .200 & .055 & .103 & $.378^{\star *}$ & $.316^{\star \star *}$ & $.271^{* *}$ & .170 & $-.207^{\star}$ & $.314^{\star \star}$ & .103 & 1.000 \\
\hline & & Sig. (2-tailed) & .009 & .052 & .593 & .320 & .000 & .002 & .008 & .100 & .044 & .002 & .319 & \\
\hline & & $\mathrm{N}$ & 95 & 95 & 95 & 95 & 95 & 95 & 95 & 95 & 95 & 94 & 95 & 95 \\
\hline
\end{tabular}

**. Correlation is significant at the .01 level (2-tailed).

*. Correlation is significant at the .05 level (2-tailed). 
Table V: Analysis of tender figures and actual contract details (Supply projects)

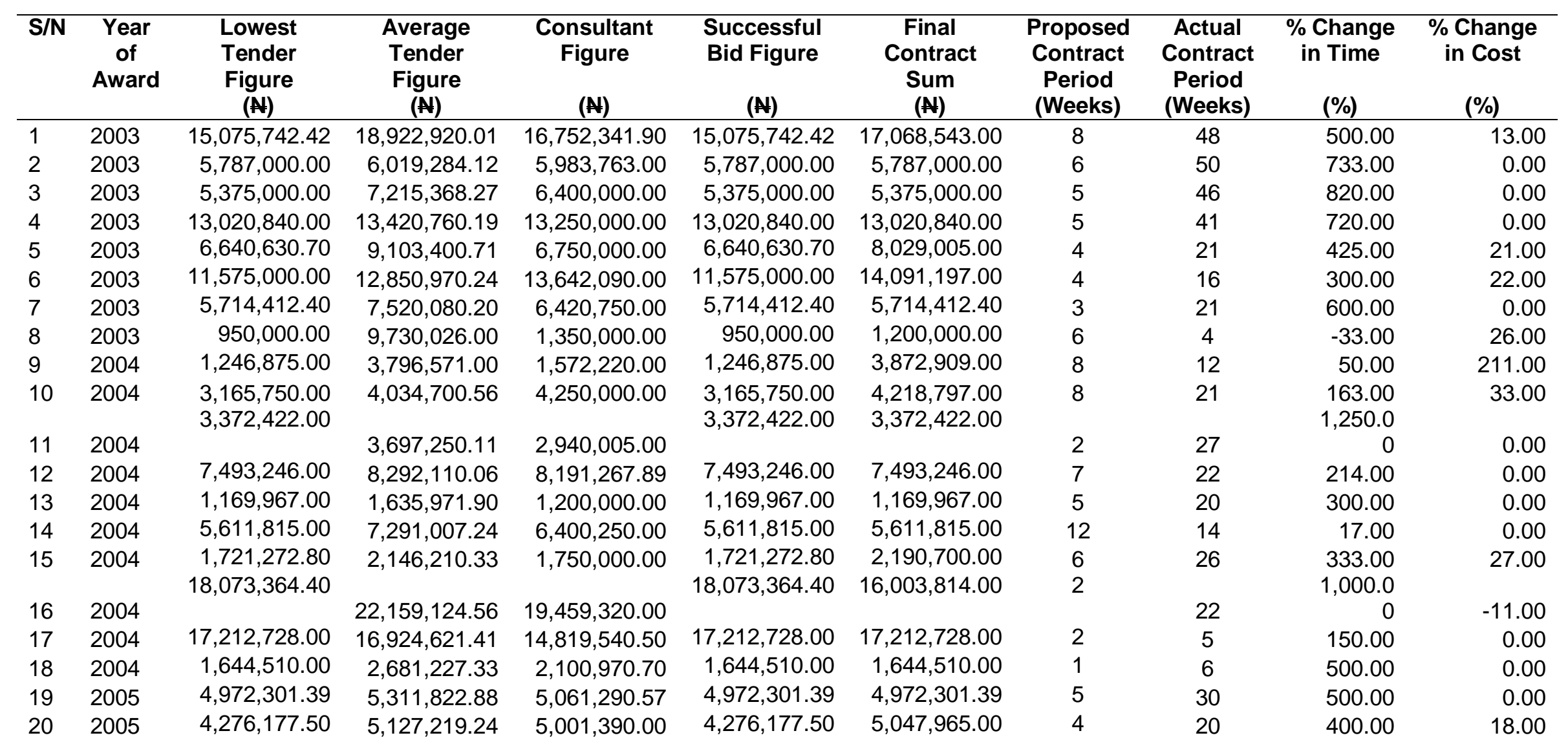




\begin{tabular}{|c|c|c|c|c|c|c|c|c|c|}
\hline 2005 & $2,708,398.00$ & $3,812,957.57$ & $3,705,000.00$ & $2,708,398.00$ & $3,704,190.00$ & 6 & 32 & 433.00 & 37.00 \\
\hline 2005 & $2,056,900.00$ & $2,729,951.09$ & $2,600,000.00$ & $2,056,900.00$ & $2,056,900.00$ & 5 & 20 & 300.00 & 0.00 \\
\hline 2005 & $13,636,875.00$ & $14,587,324.45$ & $11,549,999.99$ & $13,636,875.00$ & $13,636,875.00$ & 6 & 28 & 367.00 & 0.00 \\
\hline 2005 & $8,181,797.50$ & $8,876,234.98$ & $7,694,233.90$ & $8,181,797.50$ & $8,181,797.50$ & 4 & 19 & 375.00 & 0.00 \\
\hline 2005 & $6,716,976.00$ & $11,199,766.33$ & $10,413,981.13$ & $6,716,976.00$ & $6,716,976.00$ & 8 & 29 & 263.00 & 0.00 \\
\hline 2006 & $7,861,270.00$ & $10,100,999.67$ & $9,816,535.90$ & $7,861,270.00$ & $7,861,270.00$ & 4 & 11 & 175.00 & 0.00 \\
\hline 2006 & $20,696,025.00$ & $25,933,195.33$ & $12,053,600.99$ & $20,696,025.00$ & $20,696,025.00$ & 12 & 21 & 75.00 & 0.00 \\
\hline 2006 & $18,428,403.00$ & $41,627,978.75$ & $14,598,112.72$ & $18,428,403.00$ & $18,428,403.00$ & 12 & 16 & 33.00 & 0.00 \\
\hline 2006 & $6,354,600.00$ & $9,142,598.00$ & $9,540,834.99$ & $6,354,600.00$ & $6,354,600.00$ & 8 & 20 & 150.00 & 0.00 \\
\hline 2006 & $23,422,352.80$ & $33,277,549.62$ & $12,122,249.99$ & $23,422,352.80$ & $23,422,352.80$ & 14 & 21 & 50.00 & 0.00 \\
\hline 2006 & $9,857,400.00$ & $18,813,435.68$ & $6,861,749.99$ & $9,857,400.00$ & $9,857,400.00$ & 14 & 28 & 100.00 & 0.00 \\
\hline 2006 & $4,992,041.24$ & $4,732,783.12$ & $4,132,700.00$ & $4,992,041.24$ & $4,992,041.24$ & 4 & 4 & 0.00 & 0.00 \\
\hline 2006 & $16,236,818.10$ & $21,980,765.45$ & $17,860,499.90$ & $16,236,818.10$ & $16,236,818.10$ & 8 & 7 & -13.00 & 0.00 \\
\hline 2006 & $11,399,975.90$ & $15,504,782.90$ & $17,916,412.40$ & $11,399,975.90$ & $11,399,975.90$ & 4 & 22 & 450.00 & 0.00 \\
\hline 2007 & $4,687,585.00$ & $7,537,353.90$ & $6,546,980.67$ & $4,687,585.00$ & $4,687,585.00$ & 6 & 20 & 233.00 & 0.00 \\
\hline 2007 & $8,955,644.00$ & $9,087,636.00$ & $8,796,754.00$ & $8,955,644.00$ & $8,955,644.00$ & 10 & 16 & 60.00 & 0.00 \\
\hline 2007 & $12,376,353.00$ & $11,011,110.00$ & $12,678,543.00$ & $12,376,353.00$ & $12,376,353.00$ & 8 & 28 & 250.00 & 0.00 \\
\hline 2007 & $7,648,447.00$ & $9,778,800.09$ & $8,765,437.00$ & $7,648,447.00$ & $7,648,447.00$ & 9 & 19 & 111.00 & 0.00 \\
\hline 2007 & $8,364,740.00$ & $9,880,008.89$ & $9,876,056.00$ & $8,364,740.00$ & $8,364,740.00$ & 4 & 5 & 25.00 & 0.00 \\
\hline 2007 & $18,918,373.00$ & $21,655,229.78$ & $15,432,765.00$ & $18,918,373.00$ & $18,918,373.00$ & 8 & 18 & 125.00 & 0.00 \\
\hline 2007 & $9,784,674.00$ & $10,234,562.90$ & $7,865,098.00$ & $9,784,674.00$ & $9,784,674.00$ & 12 & 27 & 125.00 & 0.00 \\
\hline 2007 & $6,822,827.89$ & $6,431,325.66$ & $6,456,797.00$ & $6,822,827.89$ & $6,822,827.89$ & 10 & 24 & 140.00 & 0.00 \\
\hline
\end{tabular}


Table VI: Correlation Analysis of supply contract variables

Correlations

\begin{tabular}{|c|c|c|c|c|c|c|c|c|c|c|}
\hline \multirow{3}{*}{ VAR00001 } & & VAR00001 & VAR00002 & VAR00003 & VAR00004 & VAR00005 & VAR00006 & VAR00007 & VAR00008 & VAR00009 \\
\hline & $\begin{array}{l}\text { Pearson Correlation } \\
\text { Sig. (2-tailed) }\end{array}$ & 1 & $\begin{array}{l}.898^{\star \star} \\
.000\end{array}$ & $\begin{array}{l}.870^{\star \star} \\
.000\end{array}$ & $1.000^{\star \star}$ & $\begin{array}{l}.992^{\star *} \\
.000\end{array}$ & $\begin{array}{l}.350^{*} \\
.023\end{array}$ & $\begin{array}{l}.032 \\
.842\end{array}$ & $\begin{array}{r}-.129 \\
.417\end{array}$ & $\begin{array}{r}-.300 \\
.053\end{array}$ \\
\hline & $\mathrm{N}$ & 42 & 42 & 42 & 42 & 42 & 42 & 42 & 42 & 42 \\
\hline VAR00002 & $\begin{array}{l}\text { Pearson Correlation } \\
\text { Sig. (2-tailed) }\end{array}$ & $\begin{array}{l}.898^{\star \star} \\
.000\end{array}$ & 1 & $\begin{array}{l}.746^{\star *} \\
.000 \\
42\end{array}$ & $\begin{array}{l}.898^{\star \star} \\
.000 \\
42\end{array}$ & $\begin{array}{l}.892^{\star \star} \\
.000 \\
.42\end{array}$ & $\begin{array}{l}.465^{\star *} \\
.002 \\
42\end{array}$ & $\begin{array}{r}-.040 \\
.799\end{array}$ & $\begin{array}{r}-.221 \\
.160 \\
.42\end{array}$ & $\begin{array}{r}-.218 \\
.166 \\
42\end{array}$ \\
\hline VAR00003 & $\begin{array}{l}\text { Pearson Correlation } \\
\text { Sig. (2-tailed) }\end{array}$ & $\begin{array}{l}.870^{\star \star} \\
.000\end{array}$ & $\begin{array}{l}.746^{\star \star} \\
.000\end{array}$ & $\begin{array}{r}4< \\
1\end{array}$ & $\begin{array}{l}.870^{\star \star} \\
.000\end{array}$ & $\begin{array}{l}.462^{\star \star} \\
.000\end{array}$ & $\begin{array}{l}.42 \\
.120 \\
.449\end{array}$ & $\begin{array}{r}42 \\
.065 \\
.683\end{array}$ & $\begin{array}{r}42 \\
-.011 \\
.946\end{array}$ & $\begin{array}{l}42 \\
.317^{*} \\
.041\end{array}$ \\
\hline \multirow[t]{2}{*}{ VAR00004 } & $\begin{array}{l}\mathrm{N} \\
\text { Pearson Correlation }\end{array}$ & $\frac{42}{1.000^{* \star}}$ & $\frac{42}{.898^{\star \star}}$ & $\frac{42}{.870^{\star \star}}$ & $\frac{42}{1}$ & $\frac{42}{.992^{\star \star}}$ & $\frac{42}{.350^{*}}$ & $\begin{array}{r}42 \\
.032\end{array}$ & $\begin{array}{r}42 \\
-.129\end{array}$ & $\begin{array}{r}42 \\
-.300\end{array}$ \\
\hline & $\begin{array}{l}\text { Sig. (2-tailed) } \\
N\end{array}$ & 42 & $\begin{array}{r}.000 \\
42\end{array}$ & $\begin{array}{r}.000 \\
42\end{array}$ & 42 & $\begin{array}{r}.000 \\
42\end{array}$ & .023 & .842 & $\begin{array}{r}.417 \\
42\end{array}$ & $\begin{array}{r}.053 \\
42\end{array}$ \\
\hline VAR00005 & $\begin{array}{l}\text { Pearson Correlation } \\
\text { Sig. (2-tailed) } \\
\text { N }\end{array}$ & $\begin{array}{l}.992^{\star \star} \\
.000 \\
42\end{array}$ & $\begin{array}{l}.892^{\star \star} \\
.000 \\
42\end{array}$ & $\begin{array}{l}.862^{\star \star} \\
.000 \\
42\end{array}$ & $\begin{array}{c}.992^{\star \star} \\
.000 \\
42\end{array}$ & 1 & $\begin{array}{r}.363^{*} \\
.018 \\
42\end{array}$ & $\begin{array}{r}.039 \\
.805 \\
42\end{array}$ & $\begin{array}{r}-.155 \\
.327 \\
42\end{array}$ & $\begin{array}{r}-.219 \\
.163 \\
42\end{array}$ \\
\hline VAR00006 & $\begin{array}{l}\text { Pearson Correlation } \\
\text { Sig. (2-tailed) } \\
N\end{array}$ & $\begin{array}{l}.350^{*} \\
.023 \\
42\end{array}$ & $\begin{array}{l}.465^{\star \star} \\
.002 \\
42\end{array}$ & $\begin{array}{r}.120 \\
.449 \\
42\end{array}$ & $\begin{array}{l}.350^{*} \\
.023 \\
42\end{array}$ & $\begin{array}{l}.363^{*} \\
.018 \\
42\end{array}$ & 1 & $\begin{array}{r}.121 \\
.445 \\
42\end{array}$ & $\begin{array}{c}-.570^{\star \star} \\
.000 \\
42\end{array}$ & $\begin{array}{r}.040 \\
.803 \\
42\end{array}$ \\
\hline VAR00007 & $\begin{array}{l}\text { Pearson Correlation } \\
\text { Sig. (2-tailed) } \\
\text { N }\end{array}$ & $\begin{array}{l}.032 \\
.842\end{array}$ & $\begin{aligned}-. .040 \\
.799\end{aligned}$ & $\begin{array}{l}.065 \\
.683\end{array}$ & $\begin{array}{l}.032 \\
.842\end{array}$ & $\begin{array}{l}.039 \\
.805\end{array}$ & .121 & 1 & $\begin{array}{l}.576^{* \star} \\
.000\end{array}$ & $\begin{array}{l}-.121 \\
.446\end{array}$ \\
\hline \multirow[t]{2}{*}{ VAR00008 } & $\begin{array}{l}\text { Pearson Correlation } \\
\text { Sig. (2-tailed) }\end{array}$ & $\begin{array}{r}42 \\
-.129 \\
.417\end{array}$ & $\begin{array}{r}42 \\
-.221 \\
.160\end{array}$ & $\begin{array}{r}42 \\
-.011 \\
.946\end{array}$ & $\begin{array}{r}42 \\
-.129 \\
.417\end{array}$ & $\begin{array}{r}42 \\
-.155 \\
.327\end{array}$ & $\begin{array}{c}42 \\
-.570^{* *} \\
.000\end{array}$ & $\begin{array}{l}42 \\
.576^{* \star} \\
.000\end{array}$ & $\begin{array}{r}42 \\
1\end{array}$ & $\begin{array}{r}42 \\
-.159 \\
.314\end{array}$ \\
\hline & $\mathrm{N}$ & 42 & 42 & 42 & 42 & 42 & 42 & 42 & 42 & 42 \\
\hline VAR00009 & $\begin{array}{l}\text { Pearson Correlation } \\
\text { Sig. (2-tailed) } \\
N\end{array}$ & $\begin{array}{r}-.300 \\
.053 \\
42\end{array}$ & $\begin{aligned}-.218 \\
.166 \\
42\end{aligned}$ & $\begin{array}{l}-.317^{\star} \\
.041 \\
42\end{array}$ & $\begin{array}{r}-.300 \\
.053 \\
42\end{array}$ & $\begin{array}{r}-.219 \\
.163 \\
42\end{array}$ & $\begin{array}{r}.040 \\
.803 \\
42\end{array}$ & $\begin{array}{r}-.121 \\
.446 \\
42\end{array}$ & $\begin{array}{r}-.159 \\
.314 \\
42\end{array}$ & $\begin{array}{r}1 \\
42\end{array}$ \\
\hline
\end{tabular}

**. Correlation is significant at the 0.01 level (2-tailed).

*. Correlation is significant at the 0.05 level (2-tailed). 